Portland State University

PDXScholar

1982

\title{
Log structures : criteria for their description, evaluation and management as cultural resources
}

Margaret L. Glover

Portland State University

Follow this and additional works at: https://pdxscholar.library.pdx.edu/open_access_etds

Part of the Archaeological Anthropology Commons, Social and Cultural Anthropology Commons, and the United States History Commons

Let us know how access to this document benefits you.

\section{Recommended Citation}

Glover, Margaret L., "Log structures : criteria for their description, evaluation and management as cultural resources" (1982). Dissertations and Theses. Paper 3169.

https://doi.org/10.15760/etd.3158

This Thesis is brought to you for free and open access. It has been accepted for inclusion in Dissertations and Theses by an authorized administrator of PDXScholar. Please contact us if we can make this document more accessible: pdxscholar@pdx.edu. 
AN ABSTRACT OF THE THESIS OF Margaret L. Glover for the Master of Arts in Anthropology presented July 30, 1982.

Title: Log Structures: Criteria for their Description, Evaluation and Management as Cultural Resources.

APPROVED BY MEMBERS OF THE THESIS COMMITTEE:

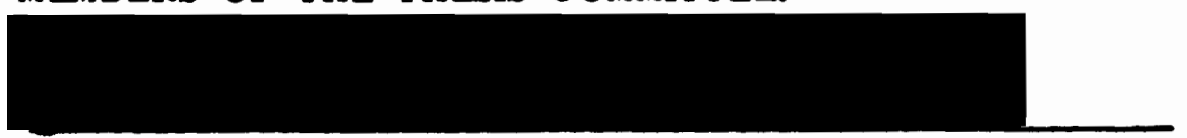

Thomas Newman, Chairman

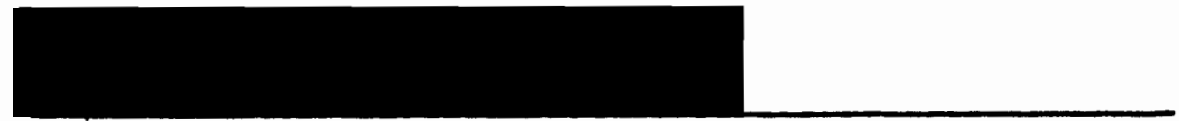

M. Ann Bennett

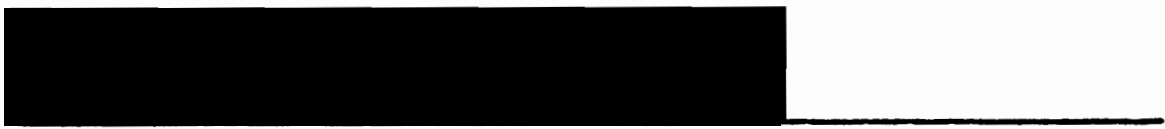

Leslie Wildesen

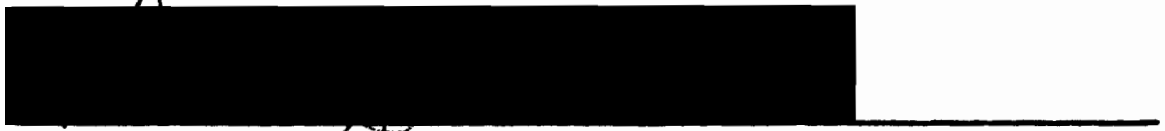

David Johnson

This thesis discusses mining cabin sites from the nineteenth and early twentieth centuries as cultural resources. Special attention is given the concept of "description" in regards to discussion of the resource category, history, and physical attributes of the sites. Evaluation and management suggestions are presented for this particular resource category. To aid in the process of identification of log cabin notching, a typology of notches is developed and presented within the context of the thesis. 
LOG STRUCTURES: CRITERIA FOR THEIR DESCRIPTION, EVALUATION AND MANAGEMENT AS CULTURAL RESOURCES

by

MARGARET L. GLOVER

A thesis submitted in partial fulfillment of the requirements for the degree of

\author{
MASTER OF ARTS \\ in \\ ANTHROPOLOGY
}

Portland State University 
TO THE OFFICE OF GRADUATE STUDIES AND RESEARCH:

The members of the Committee approve the thesis of Margaret $L$. Glover presented May 24, 1982.

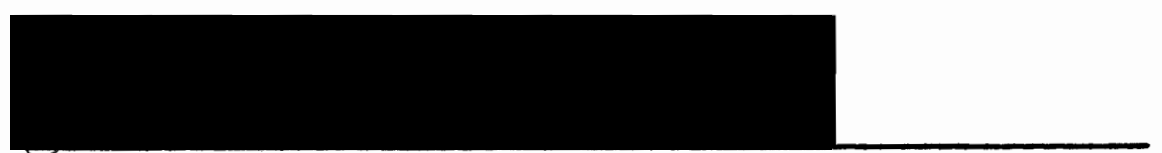

Thomas Newman, Chairman

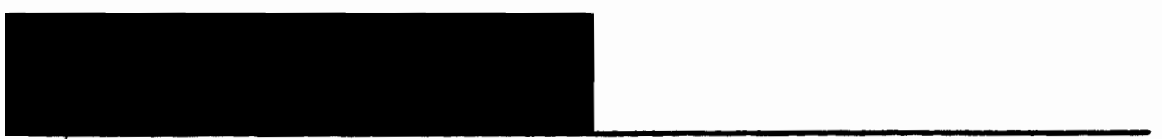

M. Ann Bennett

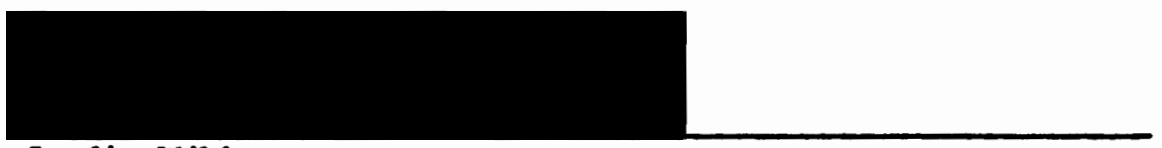

Leslie Wildesen

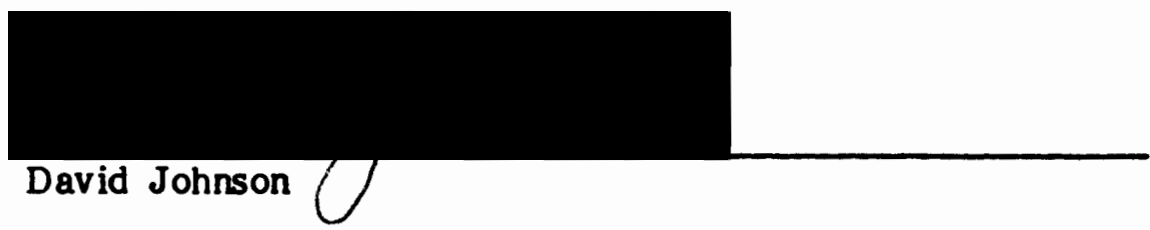

\section{APPROVED:}

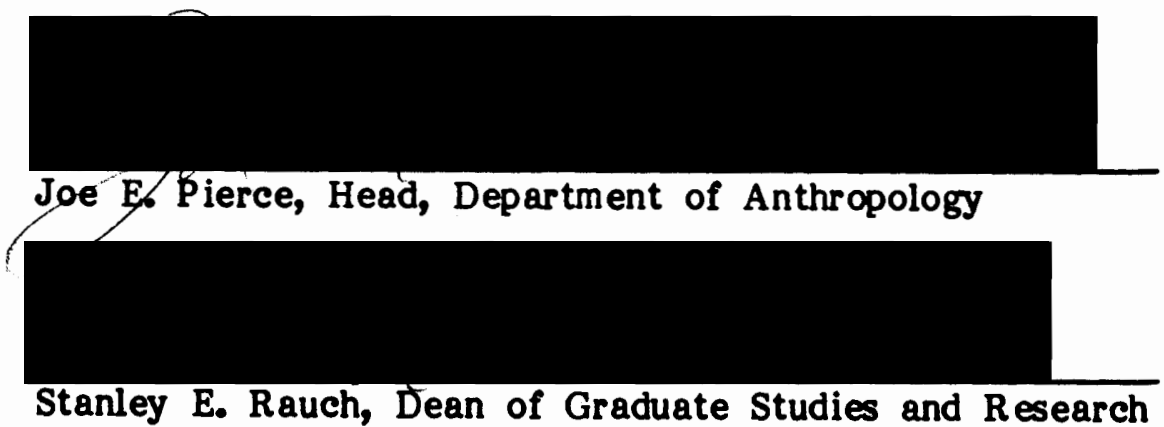




\section{ACKNOWL EDGEMENTS}

Many people and organizations aided in the compilation of the data presented here. Special thanks go to the U.S.D.A. - Forest Service, Malheur National Forest, Long Creek Ranger District, the Grant County Courthouse, and the Grant County Library. Individuals who supplied information and encouragement include: Janice Justice, Teri Winczewski, Renee Halpern, and Dan Little. Mrs. Margaret N. Glover and Jerry Grevstad helped beyond measure, and so this thesis is dedicated to them. My faculty advisors provided objective review of my earlier drafts along with the encouragement that led to all the rewrites. Thanks go to M. Ann Bennett, Leslie Wildesen, David Johnson, and my Committee Chairman, Thomas Newman, who supplied the initial topic idea. 
TABLE OF CONTENTS

PAGE

ACKNOWLEDGEMENTS . . . . . . . . . . . . . LIST OF TABLES .................... . . vii LIST OF FIGURES ................... viii CHAPTER

I INTRODUCTION ........................... 1

Significance of Research . . . . . . . . . 2 Scope of the study .............. 4

Survey of Pertinent Literature . . . . . . . . 4

II RESEARCH STRATEGY AND METHODS ......... 10

Introduction ............... . 10

Research Strategy . . . . . . . . . . . 10

Data Collection Format . . . . . . . . . . 11

Conclusions . . . . . . . . . . . . 12

III HISTORICAL REVIEW OF AMERICAN GOLD RUSH DAYS • . 13

Introduction .............. 13

Discoveries ............... 13

Government ................ 14

Economic Stimulation ............ 15

Social Situation .............. 16

Summary ................ 18 
IV THE LOG CABIN: INTRODUCTION AND CONSTRUCTION $\quad 20$

Introduction into North America . . . . . . . 20

General Use of the Log Cabin . . . . . . . . . . . 21

The Log Cabin in Mining Areas . . . . . . . . . . 23

Preference for Log Cabins . . . . . . . . . . . . 24

$\mathrm{V}$ CULTURAL BACKGROUND OF GRANT COUNTY MINERS . 31

Introduction . . . . . . . . . . . . . . . 30

1870 Census . . . . . . . . . . . . . . 30

Analysis of Dominant Mining Cabin . . . . . . . . . 35

Notch Types . . . . . . . . . . . . . . 35

Cultural Potentialities for Notch Types . . . . . . . . 39

VI EVALUATION OF THE LOG CABIN SITE . . . . . . . . 43

VII MANAGEMENT CRITERIA . . . . . . . . . . . . . 50

Introduction . . . . . . . . . . . . . . 50

Cultural Resource Management in Mining Areas . . . . 50

Federal Regulation

Activity

Structures, Features and Artifacts

Access

Seven Management Suggestions . . . . . . . . . . 54

VII SITE DESCRIPTIONS . . . . . . . . . . . . . . 57

Introduction . . . . . . . . . . . . . . . 57

Checklist A . . . . . . . . . . . . . . 58

General Information

History

Environment

Checklist B .................... 63

Structure

Artifacts

Features

Condition 
Conclusion .................. 83

IX CONCLUSIONS .................... 85

LIST' OF REFERENCES . . . . . . . . . . . . . . 87 


\section{LIST OF TABLES}

TABLE

PAGE

I Absolute Number of Miners by State of Birth . . . . . . . 32

II Absolute Number and Percentage of Miners in

Grant County in 1870 and 1880 as Compared

with Total Population Figures . . . . . . . . . . 33

III Percentage of Immigrant and U.S. Born Miners

within the Mining Sector of Grant County . . . . . . . 33

IV Percentage of "Other Foreign-Born Miners"

Listed by Country of Birth in 1870 and 1880 . . . . . 34

V Structures Observed, by Notch Type, on the Long Creek

Ranger District, Malheur National Forest, Oregon . . . 38 


\section{LIST OF FIGURES}

FIGURE

PAGE

1. The Three Most Common Notching Techniques Found within the Study Area . . . . . . . . . . 39

2. Checklist A: Final Format for Background

Research on Mining Cabins ...........

3. Checklist B: Suggested Checklist for

Recording Log Cabin Sites ............ 64

4. Square Notches .................. 67

5. V Notches ................. 68

6. Saddle Notches . . . . . . . . . . . 69

7. Dovetail Notches ............... . 70

8. Half Notches ................. 71

9. Corner Posts .................. 72 


\title{
CHAPTER I
}

\section{INTRODUCTION}

\author{
"He was a lonely miner man \\ Who in his cabin dwelt \\ Or trod the narrow trail that ran \\ Along the mineral belt.... ." \\ By James W. Galley, originally published \\ in the Sacramento Weekly Union on \\ September 14, 1872 (Lew is 1967:116).
}

While in the employ of the Forest Service, United States Department of Agriculture, in eastern Oregon, I developed a three-phase approach to cultural resource surveys. The phases are delineated as: description, evaluation, and management. Of the three, description is the most critical as neither evaluation nor management may proceed without a description of the cultural resource site. This thesis presents this approach as applied to mining activity sites with log structures. The goals for each phase may be stated as:

Description: To assemble all data necessary for the evaluation and management process while describing the physical appearance of structures, their association with features and artifacts, and supplying the known history of the site area.

Evaluation: To preserve and protect examples of mining activity which are representative of all phases of historic mining, those which are unique or display the connective network of gold mining, and which are of historical, scientific or interpretive importance. 
Management: To present a broad spectrum of management alternatives appropriate to mining sites regardless of whether or not they qualify as National Historic Register sites.

This process is the result of three seasons work, 1979-1981, recording mining sites on the Long Creek Ranger District, Malheur National Forest. This approach is designed to meet requirements outlined in federal laws and regulations and to streamline the description, evaluation, and management process.

\section{SIGNIFICANCE OF RESEARCH}

The area encompassing the Long Creek Ranger District, Malheur National Forest, Eastern Oregon, has been occupied for the last nine thousand years by various cultural groups. Euro-American culture established itself in the 1860 's through the influx of gold miners into the John Day River Valley region. Because the "Gold Rush" of the nineteenth and early twentieth centuries may be deemed a significant episode of modern American history, the Malheur National Forest is obligated, through the National Environmental Policy Act (1969), to:

...preserve important historic, cultural, and natural aspects of our heritage, and maintain, whenever possible, an environment which supports diversity and variety of individual choice.

In 1971 President Richard Nixon further outlined the government's stance on protecting America's cultural heritage:

SECTION 1. Policy. The Federal Government shall provide leadership in preserving, restoring and maintaining the historic and cultural environment of the Nation. Agencies of the executive branch of the Government (hereinafter referred to as "Federal agencies") shall (1) administer the cultural properties under their control in a spirit of stewardship and trusteeship for future generations, (2) initiate measures necessary to 
direct their policies, plans and programs in such a way that federally owned sites, structures, and objects of historical, architectural or achaeological significance are preserved, restored, and maintained for the inspiration and benefit of the people... (Executive Order 11593).

Because of these laws and regulations, the Federal Government has embarked upon the most comprehensive study ever undertaken in the field of archaeological research. The Forest Service is only one such agency involved in the inventory process. Their lands include millions of acres with thousands of years of cultural material and a myriad of physical remains. For this reason a systematic method of data recording is necessary.

The goal of cultural resource surveys is to inventory, record, evaluate, and manage identified sites. Evaluation of significance entails comparison of like sites. To accomplish this, a range of site categories must be identified, such as historic evidence of homesteading, logging, railroads or, as in this case, mining. Through background research the varieties within each category are pinpointed. This list of potential sites may then be used as a guide during the Cultural Resource Evaluation System (CRES) process. The CRES ratings divide cultural resource sites into three categories: Class I, those which qualify for the National Register of Historic Places (hereafter referred to as the Register); Class II, those which may qualify for the Register but need further investigation; and, Class III, those which do not qualify for the Register.

To meet the management goal, alternative forms of management should be outlined which will be applicable to the anticipated variety of sites for that cultural resource category.

The problem up to now has been the lack of a suitable descriptive format which takes a stance directed at evaluation and management decisions. 
This study will illustrate the descriptive process from identification through suggested management strategies for the selected site category, mining log cabins.

\section{SCOPE OF THE STUDY}

Federal laws and regulations require a determination of significance (evaluation) for each property, along with suggested management alternatives. This study approaches evaluation and management through appropriate and usable descriptions.

The resource category dealt with here is historic mining sites from the nineteenth and early twentieth centuries. Physical attributes include features artifacts and structures. Features include ditches, adits, shafts and tailings; artifacts include recovery and processing equipment, bottles, cans and other debris. This study focuses on the area of structures, more particularly, log cabins.

The results of this research fall within six topical areas: 1) the resource category of mining activity on the Long Creek Ranger District; 2) an evaluation of the resource category; 3) management alternatives for the resource category; 4) a descriptive format which aids in evaluation and management; 5) a system for typing log corner notches; and, 6) types of log corner notches discussed as being a reflection of "mining culturen, rather than of the previous national or regional cultural heritage of the miners.

\section{SURVEY OF PERTINENT LITERATURE}

Literature pertaining to the topic of this thesis touches upon several fields. Generally, research centered upon the following topics: log cabin 
history, log cabin construction, mining history, geological and mineralogical aspects of the vicinity, local history, and cultural aspects of housing. Clearly, an in-depth study of all these areas was not possible but, rather, areas of overlap were investigated. Tomes referring to these topics could not give all the necessary information, so supplementing these sources were mining records, census records, and on-ground investigation of cabins in the area.

Log cabin history has been thoroughly dealt with by Shurtleff in The Lor Cabin Myth (1939), Wesslager in The Log Cabin in America (1969), Jordan in Texas Log Buildings: A Folk_Architecture (1978), and Kniffen and Glessie in "Building in Wood in the Eastern United States" (1966). The beginnings of horizontal log construction in Europe during the Mesolithic are discussed by all of these authors with information drawn from European documents. Because of the time span dealt with, 1862 through the 1920's, European literature was not investigated. Jordan in Texas, and Knif fin and Glassie in the eastern United States, discuss the appearances of, and preferences for, certain log construction techniques in various geographical areas in the United States. Nearly all studies draw on information from east of the Rocky Mountains, creating skewed findings by not including western log cabin traditions in the data base.

Also problematic in comparative studies is the preference in the literature toward log houses, although log houses and cabins may be differentiated by noting notch types, foundations, log finishing, size, and amenities. Houses generally have hewn logs, dovetailed corners, fireplaces, more floorspace, and may have two stories. In general, cabins have unhewn logs, simpler notching, no fireplaces, limited floorspace, and only one room 
(Mann and Skinulis 1979:17; Jordan 1978:105-107). This study emphesizes log cabins. In many cases log cabins were only used for short-term habitation, while a larger, more permanent dwelling was being built with the intention that the cabin would be relegated to the status of an outbuilding. The differing emphasis in this study as compared to others precludes comparison of cabin types.

In order to understand log cabins and guide descriptive studies, the field of how to build a $\log$ cabin has to be investigated. With the "back to nature ${ }^{n}$ trend which is occurring in America, books on the subject are abundant. This investigation led to a fuller understanding of why certain techniques were used by the miners and why others were avoided. Several sources were found which were contemporary with the later (1900-1920's) structures studied, but earlier sources, Beard (1914) and Hunt (1939), use terminology for notch types that is inconsistent with the later works of Bopular Science (1952), Angier (1952), Knif fin and Glassie (1966), Weslager (1969), Hard (1977), Duncen (1978), Ritchie (1978), Jordan (1978), Bealer and Ellis (1979).

Information gleaned from these sources is presented throughout the paper, but is emphasized in the section dealing with notch types where an attempt is made to correlate and to present a clarified typology of corner not chings.

Since this study focuses on mining cabins, an investigation into the mining history was considered pertinent along with the general history of the area. Historians long have neglected Eastern Oregon to the extent that references are generally vague references to the fact that the area was settled. However, several sources provided some information, including 
Herman Oliver in Gold and Cattle Country (1961) which is a history and reminiscence by an early settler, and, Hines (1893), Gaston (1912), Lyman (1903), Scott (1924), Nedry (1952), and An Illustrated History of Baker. Grant. Malheur \& Harney Counties, written by the editors (1902), which give the more traditional dates and places. Other historical information was gathered as general knowledge and oral history from local residents.

Geological and mineralogical information pertinent in researching mining claim histories and production was obtained from Gilluly, et al., (1933) and Trimble (1914). These works aided in establishing production history of the vicinity, but generally were not useful for particular mines which were being studied. The mining records in the Grant County Courthouse provided endless frustration, not because of their quality, but because of the traditional method of recording mining claims and documenting work and improvements. Theoretically, one should be able to trace a particular mine simply by knowing the legal location. However, the legal location in the early records was not known because some claimes were filed before the U.S. Geological Survey established section lines. In lieu of the legal descriptions, claims descriptions would frequently mention the nearest stream course. But in some cases these creek names have been changed, leaving doubts as to where claims actually were. Dead ends were reached when the claim changed hands. If the name of the new owner is not known, and the name of the claim has changed, the claim is virtually lost in the records. Generally speaking, the later the records, the more precise the locational information. With records from the 1920 's it was possible to locate the claims within a square mile, which sometimes was helpfuh, sometimes not. This exercise established that it is not always possible to prove who built a cabin in 
question without an oral history informant.

In tracing a particular claim or cabin, it is necessary to have either a claim name or a claimant name to begin the investigative process, as the records are cross-referenced by those two pieces of information. If only the location is known, pure luck is needed to find any information in the records, though occasionally claim locations are given as they relate to an adjacent claim, e.g, "200 yards southeast of the Smith place".

The cultural aspects of cabins are dealt with by Jordan (1978), Shurtliff (1939), Kniffin and Glassie (1966), and, vaguely, by others already mentioned. Rapoport's House Form and Culture (1969) provided an interesting viewpoint. Although Rapoport does not specifically discuss log cabins, his concept of "temporary housing" reiterates suppositions made by others and presents them as one kind of cultural trend. Rapoport is discussed more fully later, but suffice it to say now that mining cabins may not be merely a type of frontier architecture influenced by the cultural heritage of the miners, but rather, a material testimonial of an American subculture - gold mining.

The second phase of the topic, that of evaluation and management of log structures as cultural resources, entailed a totally different type of literature search. As stated previously, a complete description is needed for proper and suitable evaluation and management. Therefore, the sources mentioned above were the prerequisite for evaluation and management. Evaluation of significance is new to the world of traditional archaeology, being spurred on by the government's dedication to preserving cultural resources. The goal is to preserve and protect objects, sites, structures, buildings and districts which are of local, state, or national importance, are 
representative, unique or illustrative of trends in American history. A guide to the selection of those things to be preserved on federally administered lands is found in 36 Code of Federal Regulations (CFR) 800. As the present study was conducted on federal land, this definition of significance was followed. No attempt was made to investigate or discuss the theoretical discussions of the evaluation process, but rather, to use Occam's razor and reduce the question of evaluation to the legal requirements of the law. The reasoning behind this is that the thesis pinpoints description as being the key to evaluation so that theoretical questions remain moot until an adequate descriptive investigation is completed.

Management of cultural resources on federally administered lands is connected to the evaluation process which is guided by laws and regulations. Investigation of this topic led to review of laws and regulations pertaining not only to cultural resources in general, but mining areas as well. Hidden deep within the subsections of mining law are areas applicable and specific to "surface resources", in which cultural resources are included. No reference is made anywhere to mining cabins and how to manage them, but the literature (law) search provided a framework for the suggested management alternatives. This topic has been left broad and flexible in federal regulations and in this study because of the uncontrollable constraints of time and money. Little would be gained by setting down rigid policies for management if those policies could never be followed. Instead, policies are reviewed and parameters presented which would enable management suitable to both the resource and the managing agency. 


\section{CHAPTER II \\ RESEARCH STRATEGY AND METHODS}

\section{INTRODUCTION}

This study is the result of three seasons' work (1979-1981) as an archaeologist for the Long Creek Ranger District, Malheur National Forest. Specific site examples are drawn from the mining sites recorded during those years and are available for inspection by contacting the Forest Supervisor, Malheur National Forest, John Day, Oregon.

\section{RESEARCH STRATEGY}

One goal of this thesis is to present a descriptive format appropriate to mining cabin sites that require evaluation and management decisions. An assessment of the resource category was compiled first and resulted in a list of observed sites, while the background, or prefield, investigation provided a list of sites which had not been confirmed. Next, management alternatives were delineated which could be applied to those sites already recorded and to those which would be recorded in the future. Finally, two site forms were designed for this resource category. The forms were tested and revised in 1980 and 1981; the final format is presented in Chapter VII (Figures 2 and 3). Because the study centered on mining sites with log cabins, a special investigation into $\log$ cabin construction was necessary to facilitate the actual descriptions and to aid in identification of unique and representative examples of log cabin notching techniques. 
This phase revealed the necessity of developing a new locally specific $\log$ cabin notch typology, as reference material lacked consistency. Because many of the literature sources suggest that $\log$ cabin notches are partially culturally determined, research into this possibility was undertaken.

A diagram best illustrates the process used for this study and as a model for all cultural resource investigations where the objectives are evaluation and management.

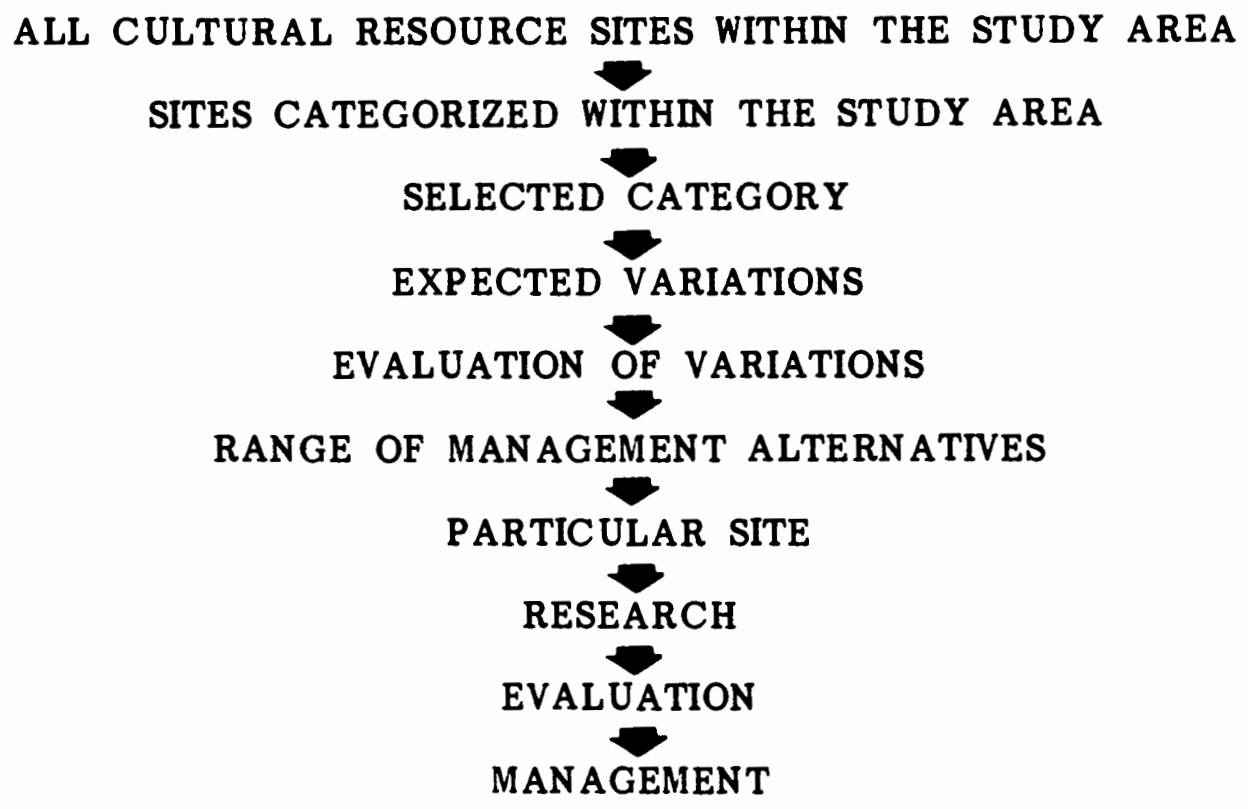

This study began with the selected category, mining sites with cabins, and continued through the last step of management.

\section{DATA COLLECTION FORMAT}

Two checklists (Figures 2 and 3 , Chapter VIII) were designed to facilitate site descriptions. These forms by themselves do not evaluate a particular site, no formula of pluses and minuses is advocated here - 
evaluators must still rely on their own powers of analysis. If cultural resource studies are systematically approached as the list of steps illustrates, then evaluation and management decisions will be more objective and uniform. Figure 2 (Chapter VIII) is the checklist for the general information which should be sought while investigating mining cabin sites. Figure 3 (Chapter VIII) is the final format for recording descriptive data about log cabins and associated features and artifacts.

\section{CONCLUSIONS}

The development of these checklists has been based on background research on mining history, $\log$ cabin history, and log cabin construction. Application of these lists initiated modifications which have improved their usefulness. Neither list will be suitable for all variations among sites, but they may be adapted to fit the resource and site forms used by various agencies.

The succeeding sections discuss: log structures; cultural background of miners; site and resource category evaluations; management suggestions; and Checklists A and B by item. 
CHAPTER III

HISTORICAL REVIEW OF AMERICAN GOLD RUSH DAYS

\section{INTRODUCTION}

Gold mining was one of the most dramatic phases of American history. The various discoveries from 1848-1896 initiated new concepts in government, stimulated the economy and displayed an unique social atmosphere. A general discussion of gold mining frontiers provides a setting for further descriptions of specific gold-mining areas and sites.

\section{DISCOVERIES}

Two gold strikes preceded the California Gold Rush - the first was in North Carolina in the 1790's and the second occurred in the 1830's in Georgia. Neither of these strikes stimulated the world like Marshall's strike at Sutter's Mill on the American River in January of 1848. George Marshall, a former immigrant to Oregon, moved on to California after staying in Oregon for only a couple of years. By July of 1848 word of his discovery reached Oregon and precipitated a massive exodus of men from the state. However, it was not until the fall of 1848 that news of the wealth of gold in California reached the east coast. The following decades were marked with intensive prospecting and rich strikes with the most notable rushes occurring in 1851 (Southern Oregon), 1852 (Ft. Colville, Washington), 1858 (Fraser River, British Columbia), 1959 (Cherry Creek Colorado, "Pike's Peak"), 1860 - silver (Nevada), 1861 (Snake River Valley, Idaho), 1861-1862 (eastern 
Oregon and Salmon River, Idaho), 1862 (Montana), 1864 (Last Chance Gulch, Montana), 1875 (South Dakota), 1876 (Black Hills, North Dakota), 1891 (Cripple Creek, Colorado), and 1896 (Klondike, Yukon Territory). The most obvious result of the Gold Rush phase of American history was that it created the impetus for settling previously uninhabited regions. Miners themselves were not the permanent settlers, but those who followed in their wake to supply necessities were. The mining advance may be reviewed as it affected three areas: government, the economy, and social situations.

\section{GOVERNMENT}

Mining communities, if they lasted long enough, passed through three phases of "government". First were laws established by miners in the formation of mining districts, second was "vigilante law", and finally, territorial or state law (Morris 1965). Of the three, district and vigilante laws were the most important in mining areas. District laws were more effective and "orderly" (Clark 1959:577) for dealing with property. Vigilante law, as described by Morris, provided "a speedy trial for law and order of fenders".

The district concept of a law-making body became tradition and eventually incorporated into U.S. Statutes. Gaston (1912:485) describes it this way:

The miners obeyed and framed rules and regulations, not only for regulating the conduct of mining but for the mode of acquiring the mines themselves, although all of them were virtually trespassers on the public domain.

Hence arose the custom, afterward embodied in the United States statutes, of allowing miners to create a mining district and constitute themselves a legislative body, whose rules and regulations, if not contrary to either Federal, State, or Territorial laws, have a binding obligation. 
In the 1890 's, with the Klondike Gold Rush, the question of "government" became international. The Klondike area rests near the boundary between Alaska and Canada. The influx of gold miners into the vicinity precipitated a boundary dispute between Canada and the United States which was effectively settled with Theodore Roosevelt's "Big Stick Policy" (Morris 1965:295). While settlement, and mining district laws, were results of the Gold Rush, the true reason for the Gold Rush was plainly personal economics.

\section{ECONOMIC STIMULATION}

Few fortune seekers actually cashed in on the wealth panned during the Gold Rush era, but the successful ones pumped millions of dollars of gold into the world market. California saw a population increase of 10,000 between 1848 and the end of 1849. Because California lacked the means of supplying food and dry goods for the people, it turned to Portland, Oregon as the immediate supplier. Economic stimulation occurred then both for the lucky miner and for those ready to provide goods and services.

The initial Gold Rush to the west occurred during a politically troubled time, just before the Civil War. Gold was undoubtedly routed back east to the financial centers and ultimately funneled into the war effort (Clark 1959:584).

The United States relied on the gold standard until 1933. Now, with the price of gold near $\$ 350.00$ per ounce, there is a new Gold Rush in progress. Roger Dierking (1980:1), Chief of Branch Records and Data Management for the Oregon State Office of the Bureau of Land Management, states: "more than a million unpatented mining claims ... have been filed 
since ... 1976". The economic impacts of gold mining may be considered on both a personal-profit level and as a century-long stimulus to the American economy.

\section{SOCIAL SITUATION}

Culturally, mining camps were the proverbial "melting pot". Those infected with "Midas-mania" came from every state in the Union and nearly every country in the world which allowed emigration (prohibited by Russia and Japan). The desire for great wealth was the personal drive for the miners, but a limited review of the world condition at the time suggests that other reasons contributed to the "rush". Political dissatisfaction was widespread in France and in the United States, and depression and famine existed in Ireland and China. Throughout the United States, Chinese were the largest single mining group, followed by the Irish (Clark 1959:585; Trimble $1914: 210,231$; Wallace 1976:109).

Anti-immigration sentiment was rampant throughout the mining frontier, but by virtue of being the earliest strike area, California led the way for laws which actually restricted the rights of some cultural groups, particularly the Chinese. Special taxes were levied only on Chinese, but they were allowed to dig for gold. Taxes were levied on all Chinese, not just those who were mining. Oregon adopted this same approach, only more strongly: the original state constitution forbade Asians from staking claims, but later they were allowed to rework tailings from abandoned claims. Resentment arose from all sectors against the Chinese because they were not considered true immigrants: most intended to return to their homeland. However, Chinese were not the only group which considered gold mining a temporary 
activity to relieve economic hardship or to foster great wealth.

The whole spirit of this phase of western expansion bore the stamp of impermanence. Nobody believed that a mother lode could last beyond the brief predictable period of time to bring the ore to the surface. (Clark 1958:585).

The most visible expression of the ephemeral nature of mining camps $w a s$ in the living accommodations selected by gold hunters. Clark (1959:574) states that "in the California gold fields houses were lacking, and men built tents, log huts, lean-to's and dugouts". During the first few days and weeks of a town's existence, residents functioned out of tents. The next step was construction of log cabins (Trimble 1914:282-283). Trimble (1914:227) explains the log cabin tradition:

Here, then, is another peculiarity of a mining camp: men seldom thought of creating homes in such a camp, and the ownership was based not on residence, as in agricultural homesteads, but on work during a portion of the year.

Confirmation of Trimble's assertion is found in the 1870 census figures for Grant County. Only $10.6 \%$ of the miners resided in family units. The others were distributed in mixed occupation lodgings (26.7\%), while $7.4 \%$ lived alone, and the largest percentage (55.3\%) were found in households comprised only of miners. An analysis of households which had at least one miner in residence shows the most popular household size as being 2-3 residents (52\%). Households of 4-6 people were frequent (25.37\%); lone miners occurred less often (15.25\%); residences of 7-11 persons were the least frequent, comprising only $6.3 \%$ of the total. These figures reflect not only the impermanence of mining areas, but the preference for small living units appropriate for the types of $\log$ cabins found in mining areas. 
Trimble (1914:146) stresses that the mining advance in general had a noticeable conformity which he readily attributes to "Californians". He finally qualifies his category by utilizing the phrase "the adopted sons of California". According to Grant County census records, this description is more accurate, because not one miner in the 1870 census was born in California. The term "49er's" is perhaps more descriptive of the itinerant prospectors who traversed the western states. In any event, the result was obvious:

There was constant migration between these various camps, which political boundaries did not seriously interrupt.

The general unity of the movement was greatly increased by the presence everywhere of Californians. ...the stratum of Californians was to be seen everywhere, and these produced throughout the region a similarity in methods of mining, in manners of society, in interests, and the sort of institutions that tended spontaneously to spring up (Trimble 1914:146).

The continuity of housing types in mining areas, and possible sources of that continuity are discussed in depth in the succeeding chapters.

Trimble $(1914: 228)$ describes this aspect of the gold-mining frontier as seen in British Columbia and perhaps offers a clearer understanding of who the "Californians" really were:

In the first place there were cabins to build and in this labor British observers admired the skill of the American axemen - a skillfulness particularly noticeable in the Missourians or those recently from the "States".

\section{SUMMARY}

The "gold rush days" began in 1848 and continued through the Klondike period of the 1890 's. Those years saw personal financial gain for a few, a new system of government designed by and for mining camps, and a 
consistent social system (evidenced in the log cabin tradition) derived from a tremendous mixture of cultures. 


\section{CHAPTER IV}

\section{THE LOG CABIN: INTRODUCTION AND CONSTRUCTION}

\section{INTRODUCTION IN NORTH AMERICA}

Log structures were not the first structures erected on American shores with the arrival of the Europeans, but rather, they came later. Shurtleff (1939) sums up the misconception that log cabins were built in the first settlements. He points out that log building techniques came from Sweden, Denmark and Germany. The first known log buildings in America were built in Swedish settlements in the 1600's. While this type of housing was not universally accepted at first, it later was adopted by those who were not the original transporters of the style. The gradual acceptance of log buildings eventually facilitated the expansion of the West from colonial times on.

Another interesting hypothes is arises from an examination of log cabin life: it would seem that the log cabin was an extremely important element per se in facilitating the internal migration of the eighteenth and nineteenth centuries (Weslager 1969:43).

During the westward push, observation, culture, previous experience, and preference mandated the style of structure. Cultural affiliation was no longer associated with the corner notching used. 


\section{GENERAL USES OF THE LOG CABIN}

Rapoport, in House Form and Culture (1969:8), discusses "primitive" and "vernacular" building styles and gives the following definitions:

1. Reimitive. Very few building types, a model with few individual variations, built by all 2. Preindustrial vecnacular $A$ greater, though still limited, number of building types, more individual variation of the model, built by tradesmen.

The log cabin tradition during the Gold Rush phase of American history boasted both "primitiven and "vernacular" construction. In 1849, a man from Curtis Creek, Californie, wrote to his wife about the cabin he and his partner built (Conway 1961:234). In contrast, the following costs were accrued from having a log house built:

In the fall of 1862 two men decided to build a house. They hired a man named Hudson to work on it and leave them free to mine. Mr. Hudson was paid $\$ 37$ for hewing logs and five days work on the house. When it was completed it cost $\$ 350$ and $w$ as the best house on the creek (Rand 1959:46).

These, however, were not the only options available. In homesteading areas another pattern of construction occurred - house raising.

In pioneer communities across North America, the building of a log house was a focal point of social activity. Logs were an inexpensive and readily available building material for settlers all across the continent. Groups of neighbors got together whenever there was a new house or barn to be raised, so that a community really built its own buildings together (Mann and Skinulis 1979:22).

It is important to stress the difference between a house and a cabin. A cabin is usually defined as a temporary, small round-log structure, while a house is larger and most often has hewn logs (Mann and Skinulis 1979:17; Jordan 1978:105-107). With the log house a community effort was common 
or, alternatively, there may have been just one person who specialized in building such structures. With the popularity of the "back to nature" movement in American culture there is a resurgence in log construction. While some resulting structures may be defined as "primitive", many are what Rapoport (1969:8) calls "high style and modern":

Many specialized building types, each building being an original creation (although this may be changing), designed and built by teams of specialists,

Log cabin or house kits may be put together by the purchaser or contracted out to a professional home builder.

American and Canadian cultures have had a continuous tradition of $\log$ construction. The introduction occurred in the seventeenth century with a direct flow of knowledge from Old World centers. Once introduced, the tradition was adopted even by those without the cultural framework for such structures. It was not long until:

...The log cabin became a symbol of the self-eliance, the courage, and the ingenuity of the American people. Because of this, from the first campaign of Andrew Jackson, who was the first of our presidents to be born in a log cabin, until the election of Abraham Lincoln, who was the last, the log cabin had great significance in American political history (Bealer and Ellis 1979:10).

Predominantly, the $\log$ cabin was built by homesteaders, miners and trappers. Throughout the United States preservationists have saved examples of log buildings. Invariably these have been houses with fireplaces, hewn logs, and the more complicated notches, such as the dovetail. These are incredible works of craftsmanship, but they were not the dominant form of structures built by American settlers. The log cabin, as defined previously, is a truer representation of frontier architecture. 


\section{THE LOG CABIN IN MINING AREAS}

The discovery of gold in California, in the late $1840^{\prime} \mathrm{s}$, was probably the greatest single factor in the settlement of the west. Tens of thousands of would-be-millionaires crowded ships and joined wagon and pack trains to reach California. Some went to get rich and return home, while others left their homes permanently. Whether they were there to pan gold or to sell the pans made some difference in the type of home that was eventually constructed. The focus of this study is the cabin built by the miners, not the merchants.

To understand the use of the $\log$ cabin, one must remember the great distances that the settlers needed to cross. Simple logistics ruled out the transportation of almost any building material in sufficient quantity to build a home. There was no guarantee of clay suitable for bricks and even less certain, for early homesteaders, was a mill for making boards. Consequently, those moving to unknown places carried with them, not material, but a knowledge of a technique which would allow for construction of some type of housing. The log cabin was the choice. While other possibilities can be thought of, European cultural heritage called for a stable, rectangular building. Teepees or conical huts could have been used by the pioneers, but generally such structures were outside the realm of possible cultural opinions. In any case, the mental image was the horizontal log cabin.

The "gold rushers" were not immune to this patterning. Specific references to log cabins in association with miners and mining camps may be found for Alaska, Wyoming, California, Montana, Idaho, Oregon and Canada. Within the physical area of this study, mining cabins were found to have the 
following descriptive parameters:

1. One room

2. Horizontal logs

3. Little or no formal foundation

4. Few, or no preservatives observed

5. Use of wood-burning stoves (as opposed to fireplaces)

6. Logs left round, or only partially hewn

7. Saddle, square, and "V" notches used exclusively

Due to the wide variation in current and historic methods of log cabin construction, the preceding attributes appear narrow and require some interpretation.

\section{PREFERENCE FOR LOG CABINS}

Any structure selected by the gold miner had to be built with materials available and had to be well adapted to the climate. Two factors emphasize the choice of log cabins over other dwelling types. Documents are available which describe the early days of mining communities as having a great number of tents. Also pertinent was the rapid construction of sawmills to manufacture boards for mining operations themselves. If mere efficiency was the main consideration, tents would never have been replaced by cabins and plank structures. If the demand for plank houses was strong enough, then the mills would have accommodated the demand. In fact, within the towns, plank and board buildings were common. While climate did not solely determine the type of structure used, climate did have some effect on the final choice of building materials. The consideration of "efficiency of construction" will be discussed later, though it may be pointed out that, in a limited way, tents were the most efficient housing type available. The major drawback would have been their ineffectiveness as shelter in the local 
climate of the study area. Tents generally do not provide much protection from snow, wind, or rain.

Four factors were considered prior to the construction of living quarters: intended use, anticipated length of occupation, time available for construction, and ease of construction. Examination of these factors reveals the total suitability of the log cabin in most American gold-mining areas.

Not only could the structure be slept in, but it also could be used for food preparation, socializing and storage of equipment (Clemson 1974:15). Obviously, tents would not react well to the heavy snow pack common in many mountainous mining regions. Structurally, sound log cabins are able to withstand the weight of many feet of snow before collapsing. Plank and board structures would be better adapted than tents, but still may not be as strong as log cabins.

The anticipated length of occupancy was a question realistically considered by miners. The long list of unsuccessful miners grew every day. No one could foretell the size of a vein of gold or the amount of gold hidden in stream gravels. More obvious in retrospect, was the rapid movement of miners when word of an even greater strike leaked out. The demand for temporary shelter then was a factor. Even when built by those other than miners, log cabins were considered well suited for this purpose.

Log cabins were often built with the intention of being abandoned, or being used later as a shed or barn or even as a summer kitchen attached to a new permanent house (Mann and Skinulis 1979:18).

In Canada the same was true:

Temporary shelter was obviously the reason for a lot of small log cabins situated in the more thinly settled parts of the province. 
Trappers, prospectors, and ranchers built many intended for occasional occupation and naturally these would be of the simplest construction and very small (Clemson 1974:15).

While modern sources bemoan the poor longevity of unpeeled log cabins built without a foundation, Duncan (1978:80) states that "naturally resistant woods remain so for a matter of 20 years or so". This would be a long enough cushion for even the most optimistic miner. In broader terms Rapoport (1969:113) discusses the time aspect of "primitive" structures in general:

...Buildings in such cultures are fairly short-lived, and are deserted or destroyed when the owner dies. This temporal relation of owner to house is a complex problem.... and attitudes toward the time dimension of the house will affect attitudes toward the problem of weathering.

The dividing line between using a tent or building a cabin has not been determined. Undoubtedly other factors such as materials, the richness of the claim, and weather conditions went into the abandonment of the tent as a poor form of shelter. Some miners did not want to spend any time away from their claims to build a cabin (Rand 1959:46). The questions of time and ease of construction are easily dealt with by the selection of a log cabin. Considerations of costs in time are not unique, and according to Rapoport (1969:115) are reflected in both primitive and vernacular building styles cross-culturally:

Materials are selected not only in terms of their adequacy for structure, tooling, laying and joining, but also with a view to the impact of time.

Concern with the time dimension is due to "direct feedback" and the need to conserve materials.

Logs were the advantageous choice in several respects. First, except in the most extreme climates, trees suitable for construction were readily available: 
[An] ... advantage for the miner is that however many trees there are on his claim, they are his. Therefore, some claims contain a good deal of value in timber and the miner can sell them or cut them down for his cabin. (Letter written in St. Elmo, Colorado, 1881)

(Conway 1961:275).

The second advantage is similar in that if logs are used, as opposed to milled lumber, the cost in time to select and transport materials is eliminated. Finally, the conservation in materials is not reflected in the log structure itself, but rather in the conservation of milled lumber. This was probably a greater concern for the miner because of his need for sluice boxes and troughs. The conservation of sawn lumber was more profitable to the individual and the community as a whole, as a plank or board structure would not only cost the miner more in effort and time, but involve the labor of others.

The actual time consumed by raising a small log structure is very short, and construction may be accomplished with a minimum of specialized tools.

The great advantage of a log cabin was that it reportedly took just two axemen only two days to put up a small, rough, eight-log (eight foot high) shelter (Mann and Skinulis 1979:17).

Once all the materials are at hand and the job is properly laid out, erection of even a large building can take place within a matter of days rather than weeks (Duncan 1978:14).

...One of the cabins described in these pages was built by one man in three days for less than two dollars... - Trappers have a number of ways of making stoves at no expense other than the pipe (Angier 1952:11).

And finally,

It was a simple job to build a log cabin where there was suitable timber available. A single man equipped with axe, saw and shovel could provide himself with a comfortable winter home in a very short time (Clemson 1974:15). 
Angier (1952:73-74) presents a lively explanation for the style and form of cabins, although his initial statement is questionable in its accuracy (as we shall see):

No set rules govern any part of log cabin construction. Log cabin builders, of ten with ingenuity and sometimes with just plain orneriness, have historically followed a single axiom, although they have expressed it in many different $w$ ays - the best you can, with what you have, right now!

Once the decision was adopted to build a log cabin, the following process, or one similar to it, was used:

To build it we first snake our logs to a skid near the site of our proposed cabin, from which we can roll our logs to our house as we need them. Lay out the corner and square them; notch the logs with a rounded or U-shaped notch. Remember that all the logs should be two or three feet longer than the walls of the proposed building, but the notches must be the same distance apart in order to make even walls. The protruding ends of the logs may be allowed to stick out as they happen to come, no matter how irregular they may be, until the cabin is erected; then, with a two-handed saw and a boy at each end they can be trimmed of $f$ evenly, thus giving a neat finish to the house (Beard 1974:164).

Log cabins and houses are customarily built without windows and doors. Once the walls have been raised, window and door locations are selected. The locations then are marked by nailing boards to the walls and then sawing along the line provided by the edge of the board. After the openings have been made, door jambs and window sills are positioned. Most log cabins observed for this study have log walls which form not only walls, but extend further to provide the frame for the gable. Shakes are easily made with a tool known as a froe. Further details of the construction of the cabins in the study are described later as they relate to the physical attributes of the resulting structure.

Cabins so constructed are anonymous by nature. While variation does 
exist, and will be discussed further on, primitive and vernacular structures lack the blueprints of more complicated types of architecture. Neither was it necessary to secure building permits nor follow safety codes or even pay property tax on the cabin. With the constant movement of miners and those who trailed them to provide other services, most cabins became as nameless as their builders.

Mining communities of the west were heterogeneous in cultural background of the miners. The 1850 census for California revealed that "Californians came from all thirty-one states and more than twenty-five countries..." (Jackson 1980:316). The first census in Grant County, Oregon was taken in 1870, a few years after the initial influx of miners. Counting only miners, twenty-five states and nineteen foreign countries were represented. Clearly, the collective knowledge of these people could have produced an array of housing types, yet log cabins predominate in the area. Not only do log cabins appear to be the norm, but the finishing and notching techniques selected are only a small sample of methods available to the builders based on their cultural heritage. 


\section{CHAPTER V}

\section{CULTURAL BACKGROUND OF GRANT COUNTY MINERS}

\section{INTRODUCTION}

The earliest available census records for Grant County date from 1870. Several problems with using these figures for this study should be pointed out before discussing the analysis of the data. First, the boundaries for the county have changed since the census; it now is smaller than it was in 1870 . This situation is not too serious as most mining was done in what is still Grant County; the number of miners added to the 1870 population total would have been small. Second, the 1870 census was taken eight years after the initial discovery of gold in Canyon Creek and after the influx of Chinese into the area to rework the placer mines. Unfortunately, no figures were gathered as to the number of Chinese involved with mining operations, nor are any details given as to their living arrangements. Finally, some doubt exists as to the completeness of the census records. For example, the Grant County Mining Records show that H. McQuaid had a series of mining claims within Grant County from 1862 through 1875, but he does not show on the census records. This omission may reflect the incompleteness of the records, or simply the absence of this individual during the collection of the census.

\section{CENSUS}

Of the 368 non-Asian men giving their occupation as miners, 59\% were born in the United States, and 38\% were born in other countries. It is 
unclear where the rest were born because of the vagueness of the information. Of those born in the United States, $79 \%$ were from only ten states, and half of those were from the northeastern states of New York, Ohio, Pennsylvania, Maine and Massachusetts. In all, twenty-five states were represented in the mining community. Only ten states then in existence were not represented in the records (Table I).

The non-Chinese immigrant miners represented 17 countries. Forty-two percent were born in Ireland, Scotland, England or Wales. Ireland dominated with 43 individuals (28.6\%). Other countries represented by at least $7 \%$ of the non-Chinese and non-native-born individuals include: Portugal (15 individuals), Prussia (13), France (11), Canada (16), and Germany (12) (Tables III and IV).

Though the 1870 census records gloss over the Chinese segment of the Grant County population, the records do say:

There were 942 chinese [sic] in this county at this time. They were mostly miners tho [sic] a few had other occupations. A Physician and a druggist. Also washer people and a few were cooks. And a very few were in white homes as cooks and general work (Federal Census for 1870:36).

In the 1880 census, the Chinese were listed separately, as were the other residents. Just over $87 \%$ of the Chinese were miners; the remainder had other occupations. Because no other figures were available, the same percentage was applied to the previous census, resulting in an extrapolated total of 826 Chinese miners in 1870. 
TABLE I

ABSOLUTE NUMBER OF MINERS BY STATE OF BIRTH IN 1870 AND 1880 AND THE PREVALENT NOTCHES IN THOSE STATES

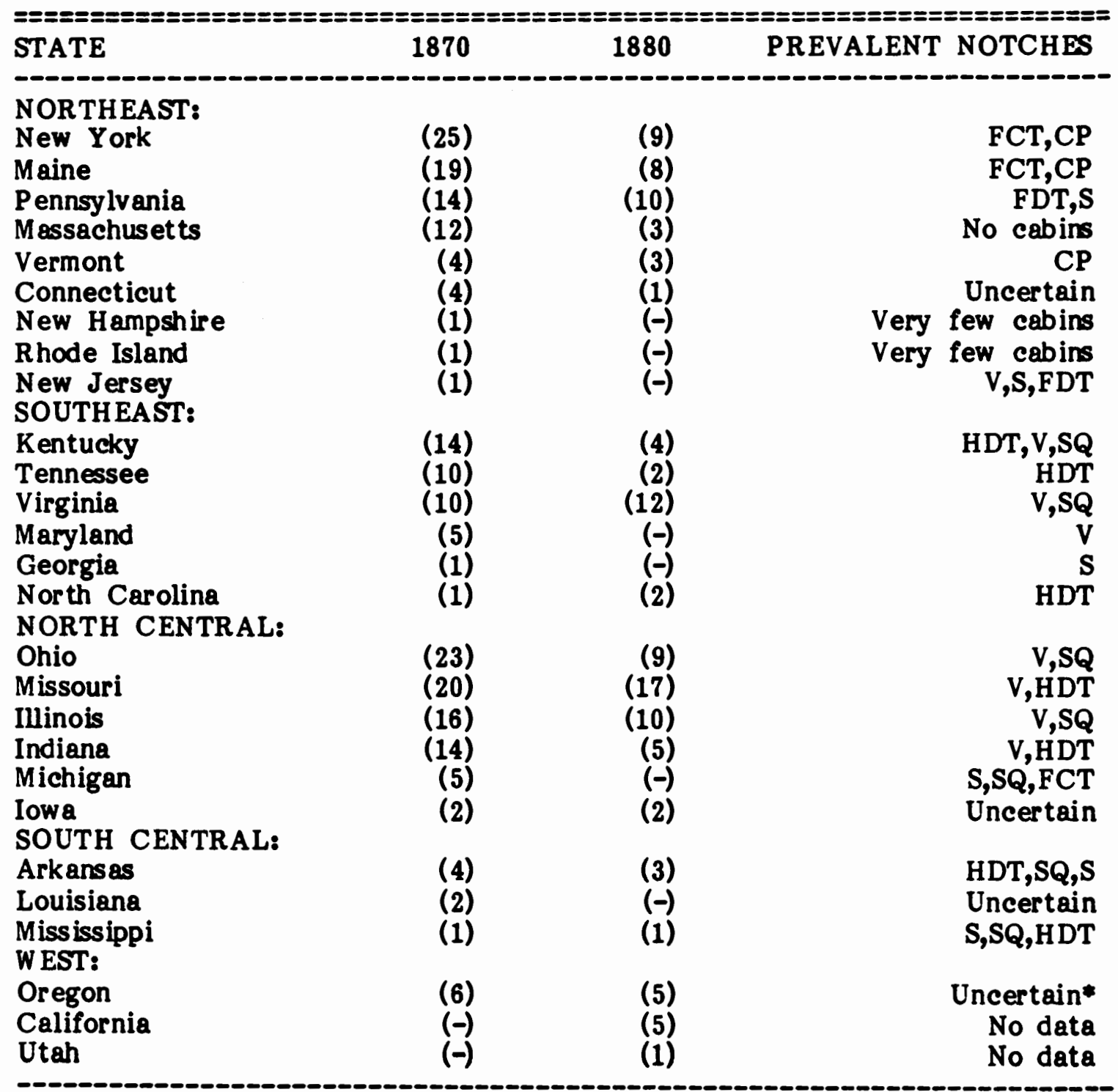

Key to abbreviations:

$V: V$ notch

S: Saddle notch
SQ: Square notch

CP: Corner post FDT: Full-dovetail
FCT: False-corner timbering HDT: Half-dovetail

*No complete inventories of log cabins have been done in Oregon, but the $V$, Square, Saddle, Half-dovetail, and Corner Post treatments have been observed by the author. 
TABLE II

ABSOLUTE NUMBER AND PERCENTAGE OF MINERS IN GRANT COUNTY IN 1870 AND 1880 AS COMPARED

WITH TOTAL POPULATION FIGURES

\begin{tabular}{|c|c|c|c|c|c|c|}
\hline & TOTAL & & NERS & ALL OTHER & OCCUP & TIONS \\
\hline YEAR & POPULATION & \# & $\%$ & & \# & $\%$ \\
\hline $\begin{array}{l}1870 \\
1880\end{array}$ & $\begin{array}{l}2,181 \\
4,309\end{array}$ & $\begin{array}{r}1,193 \\
914\end{array}$ & $\begin{array}{l}54.7 \\
21.9\end{array}$ & & $\begin{array}{r}988 \\
3,395\end{array}$ & $\begin{array}{l}45.3 \\
78.8\end{array}$ \\
\hline
\end{tabular}

Note: Figures have been abstracted from the 1870 and 1880 census records from Grant County. The absolute number of Chinese miners in 1870 is unknown and the figure presented in Tables II and III is an extrapolation based on the percentage of Chinese miners in 1880 .

TABLE III

PERCENTAGE OF IMMIGRANT AND U.S. BORN MINERS WITHIN THE MINING SECTOR OF GRANT COUNTY

\begin{tabular}{|c|c|c|c|c|c|c|c|}
\hline \multirow[b]{2}{*}{ YEAR } & \multirow{2}{*}{$\begin{array}{l}\text { TOTAL } \\
\text { MINERS }\end{array}$} & \multicolumn{2}{|c|}{ CHINESE } & \multicolumn{2}{|c|}{ US BORN } & \multicolumn{2}{|c|}{ OTHER } \\
\hline & & \# & $\%$ & \# & $\%$ & \# & $\%$ \\
\hline $\begin{array}{l}1870 \\
1880\end{array}$ & $\begin{array}{r}1,193 \\
944\end{array}$ & $\begin{array}{l}826 \\
744\end{array}$ & $\begin{array}{l}69.2 \\
82.0\end{array}$ & $\begin{array}{l}216 \\
112\end{array}$ & $\begin{array}{l}18.0 \\
11.8\end{array}$ & $\begin{array}{r}152 \\
58\end{array}$ & $\begin{array}{r}12.7 \\
6.1\end{array}$ \\
\hline
\end{tabular}


TABLE IV

PERCENTAGES OF "OTHER FOREIGN-BORN" MINERS LISTED

BY COUNTRY OF BIRTH IN 1870 AND 1880

\begin{tabular}{|c|c|c|}
\hline COUNTRY OF BIRTH & $\%$ IN 1870 & $\%$ IN 1880 \\
\hline Ireland & 28.60 & 20.69 \\
\hline Canada & 10.66 & 8.60 \\
\hline Portugal & 10.00 & 10.34 \\
\hline Prussia & 8.66 & 13.80 \\
\hline Germany & 8.00 & 6.90 \\
\hline England & 8.00 & 12.07 \\
\hline France & 7.30 & 12.70 \\
\hline Sweden & 5.30 & 3.40 \\
\hline Scotland & 4.60 & 6.90 \\
\hline Switzerland & 1.30 & 3.40 \\
\hline Poland & 1.30 & - \\
\hline Italy & 1.30 & 1.70 \\
\hline Denmark & 1.30 & - \\
\hline Isle of Florida & 0.60 & - \\
\hline Chile & 0.60 & - \\
\hline Mexico & 0.60 & - \\
\hline Wales & 0.60 & - \\
\hline Norway & 0.60 & 一 \\
\hline Totals: & 99.32 & 100.50 \\
\hline
\end{tabular}




\section{ANALYSIS OF DOMINANT MINING CABIN NOTCH TYPES}

Three notch types dominate the reported mining cabin sites in the study area: the square, the saddle, and the "V" (Figure 1). Since nearly every notching technique was known to the miners collectively, why then do only three types appear in the cabins within the study area, and then only on unhewn (round) logs? Several factors may account for the small number of notch types:

1. Ease of construction

2. Type of log species used

3. Accepted notch types in mining areas

The first two possibilities have some measure of validity, and collectively they lead to the third - namely, that these notch types may have become the accepted norm in all mining communities. Before justifying the preceding statement, factors which lead up to it must be discussed.

A small log cabin may be erected in a matter of a few days by one person, as already documented. The length of time needed to prepare both the logs and the site area may be appreciably shortened if the logs are left round and unpeeled and if notches not needing careful measurements are used. Site preparation time and effort may be reduced if the foundation is dispensed with or minimally prepared by leveling. Indeed, most mining cabins reviewed for this study exhibit these attributes, which indicate a minimal expenditure of time and effort.

Jordan (1978:35) believes that:

...Log structures made of round timbers indicate hasty, careless construction performed by minimally skilled workers. That such buildings are so widespread and numerous in Texas is evidence of the low quality of log craftsmanship prevailing in the state. Round-log 
$\theta \pi$

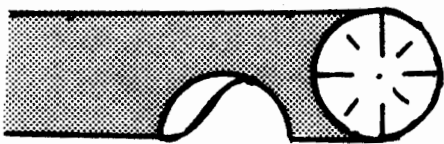

SINGLE SADDLE NOTCH DOWN
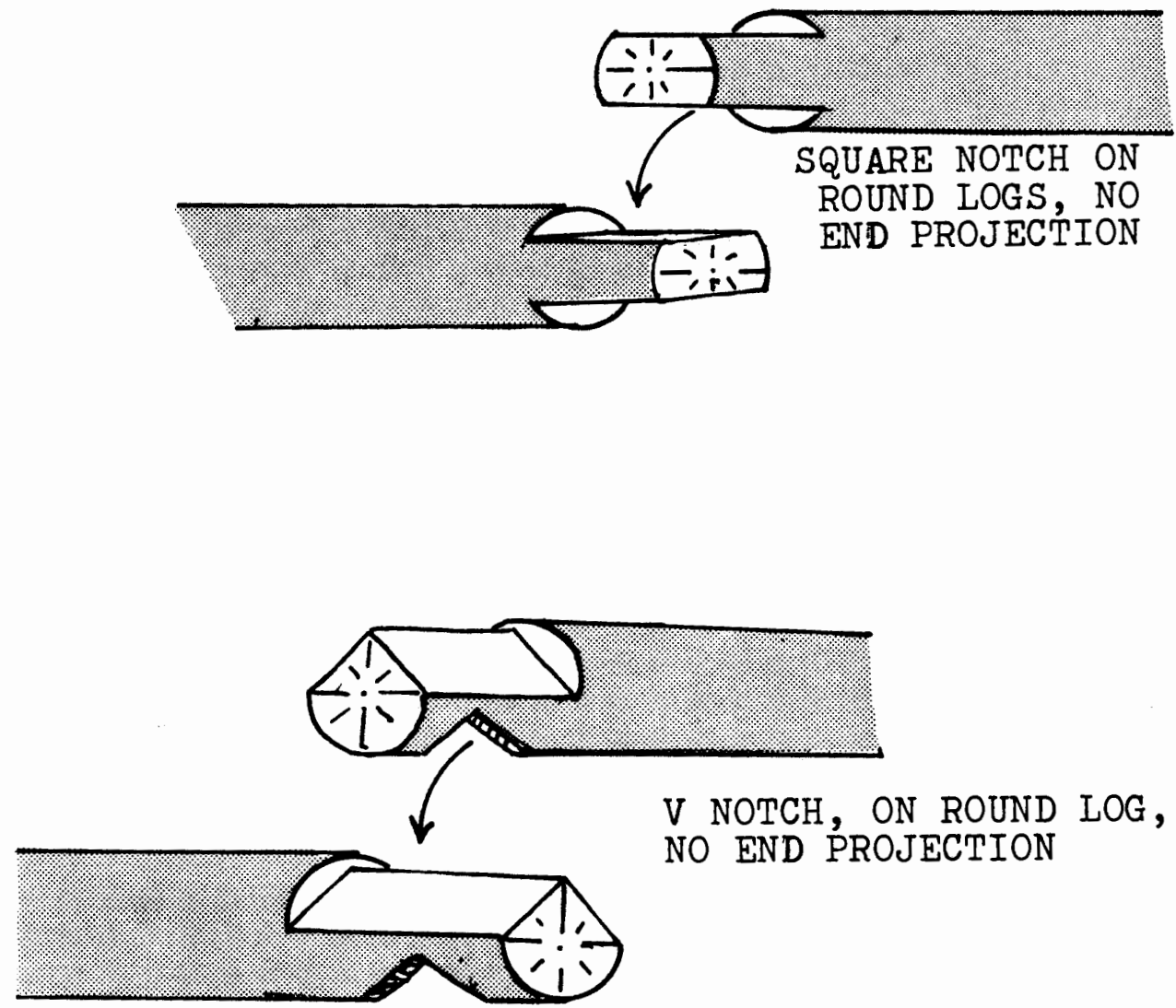

Figure 1e The three most common notching techniques found within the study area. 
construction dominated both the very early pioneer phase and the very late Depression-era period of log building in Texas. The last generation of $\log$ builders, in the $1930^{\prime}$ s, retained only this most primitive method, having forgotten the better techniques known to their grandfathers and fathers.

At variance with Jordan, log cabin notches and logs should be noted for their suitability of purpose rather than as an aesthetic symbol of the level of craftsmanship.

However, Jordan (1978:76) convincingly presents evidence which indicates that, at least in Texas, notch types are correlated to the type of wood used:

Almost half of all oaken log houses observed in Texas are dovetailed, while those built of pine are most often saddle or square notched. Cedar timbers usually display saddle or "V" notching, and all semilunate notching occurs in pine. In general, we can say that dovetailing predominates for hardwoods, while saddle, "V", square, and semilunate notchings are prevalent in softwoods. The findings in Texas strongly suggest that log "corner men" usually knew how to fashion two or more different notch styles and that they allowed the available type of timber to influence their choice among those types.

Jordan's findings are equally applicable in Oregon where softwoods predominate. The only hardwood available is western larch (tamarack). Of the structures studied, it was not possible to determine wood species in all cases. Those where bark was visible revealed a prevalence of ponderosa pine and lodgepole pine. One cabin displayed three types of wood: ponderosa pine, lodgepole pine and white fir (Glover 1981:15). The latter is an extremely soft wood subject to rapid deteriaration. The builder apparently was aware of this as the log was placed in the center of a wall well above the sill logs which suffer the most from moisture.

The final factor which may have influenced the preference for the saddle, square and "Vn notches is the assumption that those types were the 
norm. Twenty-three log structures have been recorded on the Long Creek Ranger District from 1979 through 1981 (Glover, et al. 1979a, 1979b; Glover 1980a, 1981a, 1981b). Of those, only five are not mining cabins. Table V indicates the breakdown of observed notch types:

\section{TABLE V}

STRUCTURES OBSERVED BY NOTCH TYPE ON THE LONG CREEK RANGER DISTRICT, MALHEUR NATIONAL FOREST, OREGON

\begin{tabular}{|c|c|c|c|c|}
\hline TYPE OF STF & SQUARE & "V" & SADDLE & TOTAL \\
\hline Mining cabins & 6 & 4 & 8 & 18 \\
\hline Hom esteads & $2^{*}$ & 0 & 0 & 2 \\
\hline Barns & 0 & 0 & 3 & \\
\hline Total & 8 & 4 & 11 & 23 \\
\hline
\end{tabular}

* One notch was executed as a half-dovetail, while the rest were square notches.

The structures observed reflect only a small portion of the variety with which $\log$ notches may be manufactured. The cultural backgrounds of the Grant County miners suggests that a wider variety of notch types was known to the builders than these three variants. While it is possible that the data collected on the Long Creek Ranger District is not a true representation of the notches used in mining areas, and that the builders did adhere more closely to their cultural models, this appears to be a slim possibility. In two instances, one from the study area and the one from California, miners who would have been raised without the knowledge of log cabin construction built log cabins. According to census records, the original claimant for the Princess Mine was from Ireland (Glover 1981b:52). Because Ireland is a non-cabin area, Mr. McQuaid, the original claimant and most 
likely the cabin's constructor, must have acquired the knowledge of the "V" notch after immigration to America, and possibly in other mining camps. Alan Conway (1961) assembled a collection of letters written by Welsh (a non-cabin country) immigrants to America during the timespan dealt with here. The letters frequently refer to log cabins, and one particular letter speaks of constructing one in California in 1849:

We built our cabin twelve feet by eight feet in five days, roofing it with pine tops and a tent over that so that it is completely waterproof (Conway 1961:234).

Information may never be massive when dealing with which miner built what cabin, but in at least two instances miners unfamiliar with log cabin construction adopted that housing style.

The discovery of gold, and a tradition for log cabin construction, combined together gives us a physical cultural resource category, collectively called "Mining Sites". Mining sites which combine structures, features and artifacts warrant special analysis in the process of evaluation and in the development of management alternatives.

\section{CULTURAL POTENTIALITIES FOR NOTCH TYPES}

A study of the origins of Grant County miners reveals cultural potentialities and precedents for log cabin construction and for specific construction techniques (Table I). Although, according to Kniffin and Glassie (1966) the New England states were well out of the area of log construction dominance by 1850,44 of the 216 American-born miners were from New York and Maine (25 and 19 respectively). When log structures were used in New York (and probably in the other New England states) the 
false-corner-timbering and corner post styles predominated (Kniffin and Glassie 1966:61). Ohio supplied 23 miners to the Grant County area in 1870. In Ohio the "V" and square notches dominated (Kniffin and Glassie 1966:61; Jordan 1978:65,68). Pennsylvania was represented by 14 miners, whose cultural tradition was influenced by both Swedes and Germans, as illustrated by use of the full-dovetail, saddle, and "V" type notches (Knif fin and Glassie 1966:61; Jordan 1978:49,54,58,65). Indiana's log construction is dominated by the "V" and half-dovetail notches. Fourteen miners were born in Indiana and may have carried these patterns of construction with them to Eastern Oregon. The state of Kentucky supplied 17 miners to Grant County; if they were acquainted with log construction techniques they would have drawn from the "Vn, square, saddle, and especially, the half-dovetail notch. Eleven miners were from Massachusetts where there was no log cabin tradition. The final states to supply at least ten miners to this area are Missouri, Illinois and Virginia. Missouri's notches include the half-dovetail and the "V" notches while Illinois and Virginia both share a preference for the "V" and square notches. Table I gives the predominant notch types found by state and the number of miners reported in the 1870 and 1880 census records from each state.

Non-American-born miners may be divided into two categories: Asian (Chinese) and non-Asian. This separation is made because census records do not give an accurate number of Chinese who were involved in mining, and because the Asian influence in log cabin construction may best be considered separately.

It is unwise to assert that Chinese miners did not construct log cabins, though there are three points to consider when assessing the probable impact 
of the Chinese in log cabin construction. First, there is no cultural precedent in China for log cabins; second, no evidence has been reported which attributes any log cabins to Chinese labor; and third, the Chinese were not allowed to stake claims unless for a previously worked area, and they generally worked in large groups hired out as day labor. More evidence is necessary in order to evaluate the contributions of Asians in this and other mining areas.

Of the remaining for eign-born miners, 55 came from countries with a $\log$ cabin tradition. Included in that total were: 16 from Canada, 13 from Prussia, 12 from Germany, 8 from Sweden, 2 from Switzerland, 2 from Poland, 1 from Norway and 1 from Mexico. The notch types developed in Europe may only loosely be assigned national associations, and then it is easier to give the style and the areas of occurrence. The full-dovetail occurs in Germany and Czechoslovakia, the "German" area undoubtedly being on what is now the East Germany-Czechoslovakia border (Jordan 1978:22,49). The saddle notch was probably the first notch used in horizontal log construction, dating from the Mesolithic. This notch may be geographically placed in Sweden and West Germany (Jordan 1978:58). Jordan places the "V" notch in "Germany", which is historically correct, though the Schwenkfelders he credits with introducing the notch to the United States came from Silesia, now a province in southern Poland along the Czechoslovakian border. Likewise, Jordan gives northern Bohemia as the source area for square notch. Politically, the region today falls within Czechoslovakia and perhaps the southern portion of East Germany. The double notch enjoys the widest geographic distribution, being found in the Alps region (Switzerland and Austria), the East European Plain (a portion of 
the Soviet Union), and in Finland. As clearly shown, difficulties arise when ascribing cultural traditions to dynamic and changing political states through time. The problem is increased in this instance because the census records rarely give any exact location of birth which would enable one to determine more accurately the cultural heritage of the individual. Still, only slightly less than $40 \%$ of the non-Asian foreign-born could have been exposed to log cabin construction techniques in their native countries.

If cultural heritage determined the question of whether or not the miners would build log cabins, then $93.5 \%$ of American-born miners had the knowledge, while $38 \%$ of non-Asian immigrants and none of the Chinese would have built log cabins. If Chinese miners are dropped from the roster of potential cabin builders, then over $72 \%$ of the miners had either the cultural heritage or exposure to log building techniques, certainly enough to account for the presence of $\log$ cabins in this mining area. 


\section{CHAPTER VI}

\section{EVALUATION}

With the increasing necessity of locating, describing, and evaluating cultural resources on federal lands, evaluation has become a major issue. It is acknowledged that all sites have some importance, but "how much is enough" to meet the criteria for eligibility for the National Register of Historic Places is what hundreds of federally employed archaeologists try to answer every season. Evaluation, as defined here, refers to the process of measuring a site against the National Register criteria for significance. As prescribed by 36 CFR 60.6, "significant" cultural resource sites are those that are:

A. ...Associated with events that have made a significant contribution to broad patterns of our history, or, our past, or, B. that are associated with the lives of persons significant in our past, or, C. that embody the distinctive characteristics of a type, period, or, method of construction, or, that represent the work of a master, or, that possess high artistic values, or, that represent a significant and distinguishable entity whose components may lack individual distinction, or, D. that have yielded or may likely yield information important in prehistory or history.

These criteria are necessarily broad so as to encompass all possible cultural resources from obsidian lithic scatters to historic railroads. The first and most important step in the evaluation process is to assign each site to its correct category. If this is properly done, then mining cabins will be evaluated against each other and not as they compare with homesteads or Forest Service guard stations. Evaluating for significance is one of the most 
controversial aspects of cultural resource management projects. Raab and Klinger (1977:630) delineate four methods used in evaluation procedures: 1 ) National Historic Register Criteria, 2) monetary value of each site, 3) uniqueness, (e.ge, biggest, tallest, longest, etc.), and 4) "significance as measured by an explicit problem-oriented research design". Raab and Klinger prefer the final method listed. However, Michael A. Glassow (1977:418) goes further to extend evaluations of significance to include not only research value, but sites which are representative of the particular categories:

...In conjunction with efforts to develop regional research designs oriented around current regional research interests, attention should also be devoted to identifying the different kinds of archaeological resources that a region has to of fer and plotting their distributions through time and space. By keeping in mind the objecting of preserving representative samples of these distributions in making significance evaluations we will be doing as much as we can for posterity.

The National Historic Register criteria (36 CFR 60.6) includes all methods of evaluation discussed by Raab and Klinger (1977) and Glassow (1977) with the exception of the monetary value. The evaluator should delineate within the survey/research design what method and criteria will be used during the evaluation process. As established for this thes is, the goal for evaluation is: "to preserve and protect examples of mining activity which are representative of all phases of historic mining, those which are unique or display the connective network of gold mining, as well as, those which are of historic, scientific, or interpretive importance (Chapter I).

This goal conforms with those criteria established for the National Register of Historic Places and establishes that an effort will be made to detect sites which meet those criteria. Following are discussions of mining sites as they may be evaluated against the four criteria of significance as 
presented in 36 CFR 60.6.

"...Associated with events that have made a significant contribution to broad patterns of our history": The chapter entitled "Historical Review of the American Gold Rush Days" is the result of efforts to establish the sequence of events within the Gold Rush phase of American history. That discussion outlines the general importance of historic mining activity on the national, state and local levels. Significance, in terms of "broad patterns of history" may be loosely attributed to all mining sites within the study area. Theoretically, this may be sufficient grounds for the inclusion of all mining sites in the National Historic Register, though other criteria should also be considered due to the great number of mining sites.

The second criterion, "associated with the lives of persons significant in our past ${ }^{n}$, is more appropriately considered on a site-by-site basis. Two instances came to light during the 1981 field season on the Malheur National Forest. First, Trimble (1914:277 footnote) stated that Henry Comstock, of the famous "Comstock lode", once mined on the John Day River (1862). A search of the Grant County mining claim records failed to confirm Trimble's statement in this county. Had Comstock's claim been recorded in Grant County and the location established, that site might be considered significant under this criterion. The second example of the relation of a site to a significant person was confirmed for the Buck Gulch cabins and Placer mine site (Glover 1981c, 1981d). The claimant, George Armstrong, found an eighty-ounce plus gold nugget on this claim, which received local and international acclaim for its size and purity. While George Armstrong is not as well known as George Marshall, who found gold at Sutter's Mill, or Henry Comstock, he may still be considered a significant person of our past within 
the category of "mining sites". The significance of the individual should not be judged by name recognition, but within the category within which the particular site is assigned.

The third criterion is complex in its wording and the diversity of aspects which it includes: "that embody the distinctive characteristics of a type, period, or method of construction, $\alpha$, that represent the work of a master, or, that possess high artistic values, or, that represent a significant and distinguishable entity whose components may lack individual distinction. Generally, this section is taken to encompass sites which are: representative, unique, the work of a master, esthetically pleasing, and/or a collection of individual sites which attain their importance through proximity to each other. Aspects of this criterion which are most applicable to mining sites are: representativeness, uniqueness, and sites which gain significance through their association in space and time with each other, e.g., mining districts. Once familiarity of the cultural resource category is gained by the investigator, ascribing the uniqueness or representativeness to a particular site is possible. Within the area of mining sites, establishment of a typical site profile is a complex task. To cope with the total range of site possibilities and to ensure that sites representative of historic mining in the study area would be preserved, protected and managed, the following was submitted to the Forest Supervisor, Malheur National Forest (Glover 1981a:32):

I suggest that the Forest Service attempt to locate, identify, describe and nominate to the Register cultural resources which would clearly represent the types and intensity of mining activity that has occurred on the Forest. ....

1. Artifacts representing placer and lode mining.

2. Features representing placer and lode mining.

3. Structures representing placer and lode mining. 
4. Site complexes which illustrate or represent the articulation of the artifacts, features and structures in both placer and lode mining.

5. Sites which represent the continued importance of mining in the forest, i.e., a mining claim that has a long history of activity.

6. Unique samples of artifacts, features and structures.

7. Mining districts that represent the proximity of gold claims to each other.

8. Sites which are representative of other types of mining activity, i.e., silver and quicksilver sites.

9. Sites which are likely to yield significant scientific information.

While these suggestions explain the intent of the archaeologist, they do little to pinpoint the characteristics which make a site unique or representative. The chapter entitled "The Log Cabin: Introduction and Construction" led the researcher to information which suggests that mining cabins within the study area display characteristics that differentiate them from other types of $\log$ cabins and houses. Determination of whether a site is representative or unique lies in the justification of that assertion.

A justifiable evaluation of significance based on the representative or unique nature of a site, depends on: the competence of the archaeologist, the amount of pre-field investigation, and the number of observed sites within that particular category. These aspects of significance rely on comparative studies, preferably using a statistically valid sample size. The actual number of historic mining sites on the Long Creek Ranger District, Malheur National Forest may never be determined. Factors which influence the population size, and thus the sample include: incomplete field surveys, inaccurate records, and, discrepancies in defining what should be considered a site. In lieu of a statistically valid sample, archaeologists must depend on their own subjective opinions. Researchers will have to assess the suitability of their evaluations in terms of their ability to defend them.

Sites which gained importance or significance due to their proximity to 
each other were found during the 1981 cultural resource survey for Crockett Knob Timber Sale on the Malheur National Forest (Glover 1981c and 1981d). To be nominated as a National Historic Mining District are 368 acres of National Forest land dominated by historic mining features such as: ditches, adits, shafts, and prospect holes. The vicinity exhibits a "distinguishable entity whose components ... lack individual distinetion". This, coupled with the goals presented for evaluation, and the suggested evaluative categories, supply the type of justification needed to achieve a nomination to the National Register of Historic Places.

The final aspect of the criteria for significance, M(sites) that have yielded or may likely yield information important in prehistory or history", is heavily encouraged by Raab and Klinger (1977) as the most vital of all evaluation categories. Termed as, "Problem-Oriented Research Designs", Raab and Klinger (1977:633) propose a four-phase system to accommodate their evaluation process:

(1) A detailed statement of the problem domains and the theoretical orientations to be employed in the investigations; (2) an explicit delineation of the hypotheses to be tested in the course of the study; (3) a discussion of the relevant test implication which logically follow from the hypothetical relationships stated in 2 above, as well as an explication of the data required for testing them; and (4) a detailed statement of the methodological approaches to be employed.

While Raab and Klinger's system may be of exceptionally high professional standards and applicable to some types of cultural resource programs, its suitability and practicality for intensive cultural resource surveys may be questioned. The variety of sites found on National Forest lands would require a mastery of all fields of historic and prehistoric knowledge, a capability found in few, if any, archaeologists. Broadening the 
research-oriented designs to a region-wide concern is one method of coping with the variety of cultural resource sites.

The minimum goal of cultural resource evaluations should be to preserve as many examples of our cultural heritage as is feasible. The volume of cultural resource sites being identified through government-oriented programs, scientific studies will be not able to keep pace. To prevent obliteration of sites which do not meet the demands of current or projected research questions, other evaluative methods must be utilized. If examples of sites representative of various periods of time and localities are protected, then future research projects would have a base of potential data. Management of sites chosen for protection must be suitable for the particular category and site. 


\section{CHAPTER VII \\ MANAGEMENT CRITERIA}

\section{INTRODUCTION}

Managing cultural resources on Federal Government lands begins with the data-recording process, but includes storing and disseminating information, and the more complex aspects of monitoring, protecting, enhancing, preserving, restoring, interpreting, and encouraging scientific study. The latter types of management decisions are made after the site has been recorded and evaluated. Cultural resource specialists base management options on information from survey and site reports. Acceptance of proposed management alternatives by Federal Agencies is based on well documented and justifiable suggestions which are appropriate to the type of site to be managed.

CULTURAL RESOURCE MANAGEMENT IN MINING AREAS

\section{Eederal_Regulations}

The Long Creek Ranger District, Malheur National Forest, is within an active mining area so not only are Executive Order 11593 and the National Environmental Policy Act to be followed, but also, 36 CFR 252 (Minerals) which deals with mining areas. The nature of gold mining is such that historic and current exploitation areas overlap. To provide control over impacts on surface resources during mining activity the regulations state (36 CFR 252.4): 
...A notice of intention to operate is required from any person proposing to conduct operations which might cause disturbance of surface resources. Such notice of intention shall be submitted to the District Ranger having jurisdiction over the area in which the operations will be conducted. If the District Ranger determines that such operations will likely cause significant disturbance of surface resources, the operator shall submit a proposed plan of operations to the District Ranger.

These regulations assume that the District Ranger will be informed as to the surface resources present with the impact area. Cultural resource survey reports contain descriptions, evaluations, and management suggestions for identified cultural resources which are necessary in determining impact of disturbance. If such a report has not been made, then adverse impacts on cultural resource sites may occur.

Unless otherwise agreed by the authorized of ficer, operator shall cemove within reasonable time following cessation of operations all structures, equioment and other facilities and clean up the site of operations (Emphas is added).

The Culturel Resource Survey for Mining Cabins (Glover 1981a:25) submitted to the Supervisor of the Malheur National Forest, projects the negative impacts on the Long Creek Ranger District if all mining sites, whether active or inactive, are not adequately recorded:

The Cultural Resource Overview for the Long Creek Ranger District lists 144 cultural resource sites of which 46 are attributed to mining activity. If those sites are on active mining claims, potential loss of $32 \%$ of the Cultural Resource Overview sites may occur if they are not confirmed and evaluated prior to the approval of the operating plan. This percentage may be increased if non-mining related sites are included.

Clearly, two problems exist if the inventory-evaluation process is not followed: 1) a potential loss (of) nearly one-third of the cultural resources overview sites on the Long Creek Ranger District and 2) a systematic loss of $100 \%$ of all structures on mining claims. Because the mining vicinity must be at least partially returned to its original state, the claimants may also be obligated to flatten any historic evidence of mining that they have not previously disturbed along with 
evidence of their own activity.

Executive Order 11593 specifies that "federally owned" sites and structures are to be administered as cultural resources. Mining cabins being occupied or used by valid claimants may not be included within the realm of government jurisdiction and thus, may be exempt from all cultural resource laws and regulations. Since 36 CFR 252 allows the District Ranger to use discretionary approval, the following management system encourages the protection of mining cabins which may not normally be considered within the scope of federally owned sites.

Excluding the regulatory differences between mining and other types of cultural resource sites, management of mining sites includes a range of considerations not utilized in management decisions for other cultural resources. Management options should be based on data collected on activity, structures, artifacts, features, and access.

The following sections present the type of information which should be utilized in preparation of management suggestions for mining sites, along with examples and explanations for data interpretation.

\section{Activity}

Ownership. To manage sites as cultural resources, the legal owner must be identified. Ownership of mining sites and structures may be found in county deed and claim records. In some cases, it may be possible to record and evaluate private property pending final conveyance of ownership to the Federal Government. If the site is government property, then all appropriate mining and cultural resource laws and regulations must be followed.

Claim_Activity. Mining sites have the characteristic of extended 
occupation and exploitation of the same area. Without monitoring, historic mining sites may be disturbed by current mining activity. Management alternatives may include prohibition of current and future mining activity, operation of the mining claims with restrictions so as to maintain site integrity, and unrestricted use of the site for mineral exploitation.

Qcaupancy. If the structure has an authorized occupant, then the management alternatives may have to be adapted so as not to infringe on the rights of the occupant. Sites under "special-use" permits must meet certain governmental requirements in regards to safety, cleanliness, and general maintenance. It may be possible to include specific cultural resource regulations within the special-use permit which would protect, enhance, or maintain the site's integrity.

Unauthorized, or trespass occupancies, may require intervention by local or agency law enforcement of ficials. In most cases, management alternatives are more effective when trespassers are evicted from the structure or site area.

Planned and Projected_Ground-Disturbing_Activities, Most cultural resource surveys performed on federal lands are done to meet legal requirements for environmental assessment reports. Survey or site reports should specify the activity which necessitates the cultural resource survey. Management suggestions should then deal with that project (e.go, road construction, timber harvest, reforestation, etc.). Depending on the evaluation of significance, the project may need to be halted, redesigned, or allowed to proceed as planned.

\section{Structures, Features and Artifacts}

Logistically, management options will differ with the size and 
complexity of the site. For example, fencing off a 340-acre site is more time-consuming and expensive than fencing of a two-acre site. Those who review management suggestions will need to know the number of structures, size, condition, etc, if they are to analyze the management report.

Management suggestions which deal directly with the physical appearance of the site must allow for any vandalism, natural deterioration, man-caused disturbance, and hazards. Both verbal descriptions and photographs will assist in supporting the recommendations. Hazards may either need to be mitigated or the site secured to prevent injuries.

\section{Access}

One management suggestion entails preparation of the site for public interpretation. If the site is within the boundaries of a prescribed roadless area (motorized vehicles prohibited) then public interpretation would not be a viable management alternative. Other factors which would be adverse to accessibility include: steep terrain, dense vegetation, and in some cases, rough terrain. While these factors might not prevent the site from being selected for public viewing, they would have to be dealt with in a suitable manner.

\section{SEVEN MANAGEMENT SUGGESTIONS}

In a report submitted to the Supervisor of the Malheur National Forest (Glover 1981a:33), seven management suggestions suitable for active and abandoned mining sites were presented. Implicit within the suggestions is the minimum requirement of site recording. This basic step would limit the potential for inadvertent destruction during mining operations. 
Once a property or resource has been recorded then management must be proposed and initiated. Several options are available to the Forest for the management of mining cultural resources. In increasing order of complexity they are:

1. Non-Management - This option entails no action beyond the initial description and evaluation. The resource is left in the condition found, with no attempts at preservation, protection, enhancement or monitoring. In a sense, the resource is left to the elements and vandals.

2. Monitoring Management - This option exceeds non-management by monitoring deterioration and changes in the resource. This strategy can be valuable in recording the effects of Forest Service activities in some areas. Valuable in future management and mitigation actions.

3. Guided Monitoring - The strategy would be useful in the situation where the resource has continued use, i.e., mining structures. Guidance would take the form of authorized changes in the property so as to protect its integrity. This would also enable the Forest Service to protect the site against adverse impacts caused by road construction, logging, etc.

4. Enhancement Management - Would be used on properties where the property might be better represented if certain conditions were altered, i.e., planting trees to mask something not keeping with the integrity of the site.

5. Preservation Management - Includes monitoring, and enhancement, but extends further to preserve the resource. In the case of structures, attempts at pest control might be instigated or retimbering of the adit might be done.

6. Interpretive Management - This strategy would be used for those properties that lend themselves to public interpretation. The nature of this management is such that the Guided Monitoring, Enhancement, and Preservation Management would have to be part of the scheme.

7. Scientific Management - These sites would be protected and reserved for scientific study and excavation to further knowledge of that type of resource.

These management alternatives, while not exhaustive, encompass the parameters within which cultural resources can be managed. Management of cultural resources is not contingent on the point of whether or not the property is eligible to the Register. Non-Register sites could be managed in any of the seven ways suggested, although justification of the allotment of time and monies would be essier if the site were of Register quality.

Well chosen management strategies may serve to protect, enhance, preserve, and interpret cultural resource sites for the scientific community and general public. To increase the likelihood of an appropriate management plan, the description of the resource must be clear, concise, complete, and 
usable. Therefore, deficiencies in any area of the description will lower the credibility of the evaluation and may affect the suitability of the chosen management strategy.

The following chapter, "Site Descriptions", presents a descriptive format which will aid in the description, evaluation, and management of log cabirs on mining sites while meeting both scientific and legal requirements as applied to cultural resource studies. 
CHAPTER VIII

SITE DESCRIPTIONS

\section{INTRODUCTION}

Review of the literature points out that there is no one source which outlines what is necessary in the "description" of $\log$ structures as cultural resources. I attribute this deficiency to the current use of the term; as most widely used, it refers to the physical attributes of the structure. If both evaluation and management must be based on only physical descriptions, then there will be a vast array of material not considered. I will use the following three-part definition for the term description as it applies to log structures as cultural resources:

1) The physical characteristics of the structure and of the associated features, such as mining adits, railroad grades, fences and outbuildings, including such features as dimension, size, etc.

2) Pertinent geographic information, such as the structure's location in relation to the nearest water source, railroad, and town at the time of occupation, in addition to the standard legal description.

3) A specific and regional history of the structure in accordance with its original and intended uses.

The purpose of the proposed Descriptive Format is to collect enough information to evaluate accurately and suitably manage mining cabin sites. While checklists have been developed for log cabins in particular, Checklist A (Figure 2.) is appropriate for any historic site with only a few alterations. Specifically, the checklists will: 1) give the name and location of the site, 2) the known history of the site and/or locality (where important or known), 3) 
the site's placement within the geographic area, 4) environmental placement, 5) a physical description, and 6) an assessment of the site's hazards and condition. To evaluate a $\log$ cabin, the structure itself often is not the only nor the most important factor in interpreting significance. A site's significance rests on a combination of factors - the evaluation process. Having already established the significance and impact of historic gold mining within the study area, placing particular sites within the resource category is necessary.

\section{CHECKLIST A}

\section{General Information}

Location. Minimum locational requirements include: county, Township/Range/Section, U.S.G.S. Quadrangle name, and location on the Universal Transverse Mercator Grid. (Most standard archaeological and historical site report forms allow for this information.) The site report should also contain the site location on a standard topographic map, and appropriate sketch maps of site area and structures. It is not uncommon for locational information gleaned from historic sources to differ from currently placed locations. If this has occurred then it should be mentioned within the text of the report. Some site locations are held confidential under the Freedom of Information Act so are not readily accessible to the general public.

Name. Three basic name categories are generally used in referring to mining sites: 1) Claimant's name, either former or current, 2) Claim name, either former or current, and 3) Name assigned by the reporter. The first two categories are usually popular names known by the public or are cited on maps. The final category, while seemingly arbitrary, should be based on some 


\section{GENERAL INFORMATION}

1. Legal Location

2. Name of Structure/Claim

3. Occupant

\section{HISTOR Y}

4. Mining History

5. Land Status History

6. Oral History

7. Historic Geographic Placement

\section{ENVIRONMENT}

8. Vegetation

9. Water Source

10. Geology

Figure 2. Checklist A. Final format for background research on $\mathrm{mining}$ cabins. 
nearby geographic feature. Creek names are the most easily applied to mining sites, as such sites are usually located near water. Should additional sites be found on the stream course already used, then further designations may be made by the following methods: Deadwood Creek-East, Mouth of Granite Boulder Creek, Upper Lemon Creek, etc. Sites do not have to be assigned names, but it is sometimes more convenient than referring to them by number.

Qccupant. Some sites are occupied during the mining season. If the site is on federally administered land, then prior approval for occupation must be obtained from the responsible agency, although trespass occupation is not uncommon and often is difficult to detect. If a question arises as to the validity of the occupation, inquiries may be made to the responsible agency. The necessity of establishing the identity of the current resident is to emphasize the right of the claimant and to assist in determining management decisions (previously discussed). Exterior inspection will probably not be denied to the recorder, but permission should be obtained before recording data. This action will protect both the occupant's possessions and the integrity of the field personnel. Whether occupation is valid or in trespass, the same consideration should be given to the resident.

Finally, the structure may be deteriorated, and may show no signs of recent habitation. This situation allows for the most complete and unhampered reporting of the site. The report, at a minimum, should indicate if the site is occupied, unoccupied, occupied in trespass, seasonally, year round, or abandoned.

History

Mining History. County Records: County records can help to provide the mining history of a site if one or two pieces of information are known: 
either the claim or claimant's name. These may be established through oral history or from maps. Without either of those, the county records are nearly useless. All claims are listed by the locator or the name the locator gave. Except in the more recent records, locational information is arbitrarily given but it usually falls within the following categories: legal location, Mining District, or creek. Individuals are allowed to hold more than one claim, with certain restrictions, and this may further confuse the investigator.

Bureau of Mines: Periodically the U.S. Bureau of Mines investigates certain mining districts or regions. The study area has been the center of several of these studies. While they do not discuss all mines in the area, they do discuss the major ones and the general activity in the area.

Other resources: Historical journals, newspapers, and old maps can provide information helpful in the discussion of the history.

Land Status History. The mining history of a site is most important, but the status of the land and the series of ownerships is an important part of the history. The U.S. Forest Service cooperated in the preparation of this thes is by providing access to their Land Status Atlas. This volume lists all the areas that were originally proclaimed part of the Blue Mountain Forest Reserve in 1906, lands acquired by exchange (date and name), any rights of way, e.g., Sumpter Valley Railroad, and various other encumbrances which might restrict mining or homesteading.

Oral History. In active mining areas, local miners may be able to provide the investigator with information. Checking the facts is always important and should be routinely done.

Historic Geographic Placement, This information is the outgrowth of the specific mining history, oral history, and consultation with historic maps. Even without specific history this information may be presented in such a 
way that the site fits in with the surroundings. Types of information may include: distance to the nearest main travel route, railroad, or coach line, and the distance to other mining sites. These facts are independent of the site's specific history, but depend on the investigator's knowledge of the resource category and the area.

\section{Environment}

Vegetation. Vegetation is routinely recorded for all cultural resource sites. The importance of this data item for mining sites is to help determine the type of trees used for the cabin, and also to encourage the investigator to note any plant species which could have been brought in by the miners, e.g., an apple tree. Plant species are also a good indicator of the type of bedrock.

Water Source Most claims are near some type of water. Placer claims usually are located on creeks and hard rock mines are often near stream channels. The cabins are also easily accessible to water for obvious reasons.

Geology. The development of gold within the earth's crust provided the original impetus for the American Gold Rush. A discussion or history of mining sites without reference to geology would be incomplete and indicate a lack of understanding by the reporter. The geology of the area may be established by observation, geologic maps, or through literature search. Investigation into the geologic makeup of the site area may lead to records regarding the production history of the particular site in question but also stresses the impetus behind the occurrence of the site. 


\section{CHECKLIST B}

The description of the structure should be as complete as access and safety precautions allow. Hazardous areas should be assessed upon the initial inspection of the site. Checklist B (Figure 3.) provides a basic outline for data collection. It would have to be adapted for altered structures, ones with more than one story, or other factors not allowed for within the checklist. The checklist was designed for log cabins, based on books which discuss that method of construction. The rationale for utilizing construction manuals as the source guide is that they pinpoint the important attributes and illustrate the options available to the builder. Future comparisons of these data will enable the researcher to assess uniqueness, spot patterns, and further refine the data collection format. While the physical description is only part of the site description process, many aspects of evaluation and management will deal directly with the structure so the data collected must be as complete and accurate as possible.

\section{Structure}

\section{Exterior.}

1. Dimensions: Most mining log cabins are rectangular and easily measured by metal or cloth metric tapes. Some are not as symmetric as originally intended because of deterioration and collapse. Working around the debris and fallen logs, the outside ground level dimensions should be recorded.

2. Foundation: To save time and energy during construction, few mining log cabins have foundations. When present they may be: flat rocks, log pilings, and more recently, cement blocks. If the 
RECORDED BY:

HAZARD:

SOURCE:

NUMBER OF STRUCTURES:

NAME AND/OR NUMBER OF STRUCTURE:

LEGAL LOCATION OF SEC. T.

R.

MERIDIAN

EXTERIOR

STRUCTURE

1. Dimensions

2. Foundation

3. Cornering

4. Logs
A. Type (species)
B. Finish
C. Diam eter
D. Chinking
E. Number

5. Door(s)

6. Window(s)

7. Roof Covering

INTERIOR

8. Cellar

9. Floor

10. Interior Wall $F$ inish

11. Shelves/Cupboards/Hooks/Nails

12. Windows

13. Heating/Cooking Area

14. Ceiling

15. OUTSIDE STRUCTURE

ARTIF ACTS

16. INSIDE STRUCTURE

FEATUR ES

17. TYPE (Prospect holes; adits, shafts, and tunnels; tailings; and ditches)
A. Size
B. Relationship to Structure

18. VANDALISM

CONDITION

19. DETERIORATION

20. ALTERATIONS

Figure 3. Checklist B. Suggested Checklist for recording log cabin mining sites. 
ground has a slight slope, foundation pilings or rocks may be found only on one end in order to level the floor. Foundations permit airflow and also raise the sill logs (lowest ones) off of the ground. Most deterioration occurs because sill logs absorb moisture from the ground. If air space was allowed by the builder it may have also been screened off to prevent nesting of small animals.

3. Cornering: Three particular corner notch types dominate the mining

cabins on the Long Creek Ranger District, Malheur National Forest, the saddle, the "V", and square notches. It was initially hoped that the notch type utilized on a structure would reveal the cultural origins of the builder, but this has not proved possible. Analysis of collected data (1979-1981) suggests that the notch type used by the miners is not so much a reflection of their cultural heritage but more importantly a factor of the mining culture, materials, and reason for construction. As already discussed, other options were available to the American miner which were not selected. This fact, coupled with the physical data, suggests that the attributes noted (notch types) reflect the cultural norm of the mining community, though regional comparisons are necessary to test this hypothesis. Because data recording procedures differ from archaeologist to archaeologist, and typological categories now in use are not uniform, the following classifications are presented to minimize different recording practices. Six major typological divisions exist within horizontal log notches: Square, "V", Saddle, Half, Dovetail, and Post Corner. Owing to the diversity of names 
and general stylistics, sometimes new and more explanatory names have been assigned in this thesis. Within each of the major categories there are two factors which affect the appearance of the resulting notch. The first is the treatment of the $\log -$ whether it has been hewn square or left in the round. The second is the length of the end projection. This is especially noticeable in the square and "V" notch categories. (See Figures 4-9.) Verbal descriptions may sometimes contain as many as three descriptive terms: category, log treatment, and extension. For example: Square-hewn-extended, Square-round, V-round, and V-round-extended.

The saddle category has three recognized types: Single-up-saddle notch, single-down-saddle notch, and the double-saddle notch. Saddle type notches are always fashioned near the end of the log and used only on logs left in the round so no other subdivisions are necessary.

Three subdivisions of the half notch were found. The first two involve removal of half of the end of round logs, while the second is used on square logs, again removing half the log end. (See Figure 8).

The dovetail category is rarely found in mining cabins, probably because of the large expenditure of time necessary for the hewing. Most commonly the dovetail is used on squared logs, although infrequently the log is left in the round. The major distinetions in the squared logs are between the full- and half-dovetails. The half-dovetail notch has two ninety-degree angles while the 


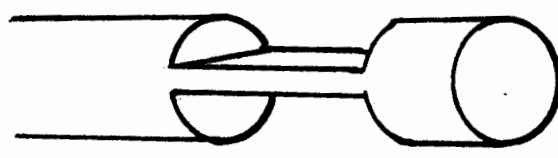

A

SQUARE-ROUND-EXTENDED

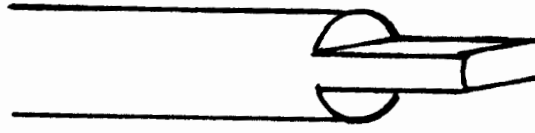

B

SQUARE-ROUND

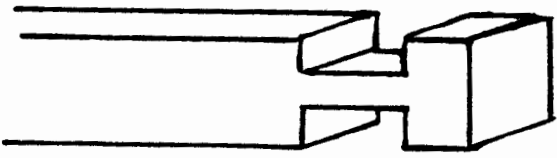

C

SQUARE-HEWN-EXTENDED

D SQUARE-HEWN

\section{E CUBE-HEWN \\ SQUARE}

Figure 4e Square notches.

Other names assigned to these notches:

A. Lock Notch Variation \#1

Tenon Corner Joint

Tenon

B. Dovetail Joint

Tenon Corner

Square Notch/Round Log

Square Lap/Round Log

C. Double Notch

Double Notch Square

Sawn Lines

Square Notch

D. Square

Tenon Shaped

Common Lapped Joint

E. Square Notch
Angier (1952)

Duncan (1978)

Hard (1977)

Hunt (1939)

Mason and Kock (1947), Angier

(1952)

Jordan (1978)

Mann and Skinulis (1979)

Kniffen and Glassie (1966),

Weslager (1969)

Brimmer (1929)

Mason and Kock (1947)

Kniffen and Glassie (1966), Weslager

(1969), Bunten and Walton (1980)

Mason and Kock (1947)

Mackie (1977)

McRaven (1978) 


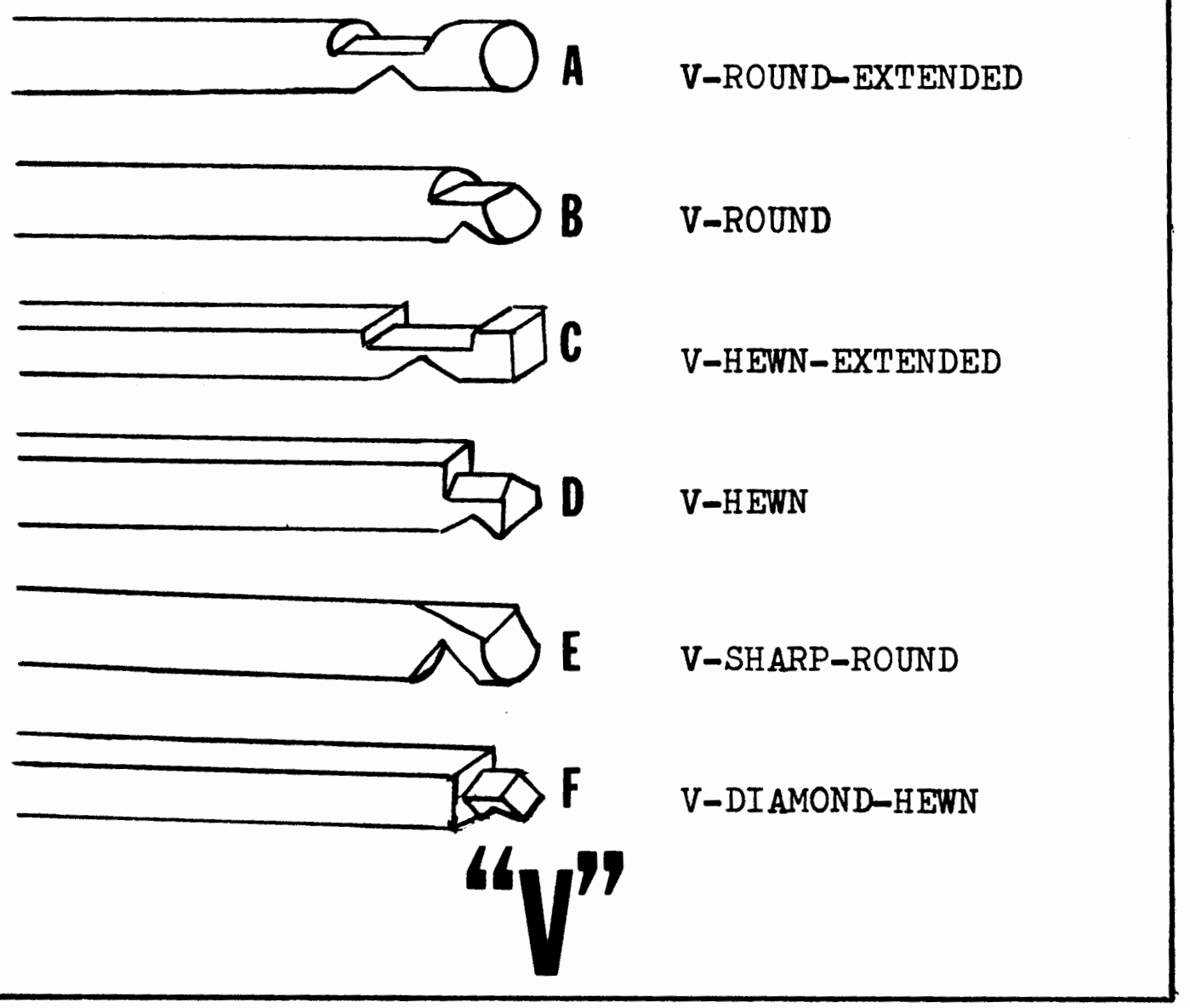

\section{Figure 5e V notches.}

Other names assigned to these notches:

A. AV Joint

AV Corner Joint

Lock Notch-Variation \#2 Pike Joint

\#6

Saddle

B. Saddle Notch

Saddle Notch CloseCut End

$\checkmark$ Notch

C. \#3

D. Pennsylvania Corner $\checkmark$ Notch

Indented $\mathrm{V}$ Notch

E. Sharp Notch

F. Diamond
Hunt (1939), Ritchie (1978)

Duncan (1978)

Angier (1952)

Beard (1974)

Popular Sclence (1952)

Mason and Kock (1947), Mackie

(1977)

Wiggington (1972)

Mackie (1977)

Kniffen and Glassie (1966), Jordan (1978)

Popular Science

Mann and Skinulis (1979)

Kniffen and Glassie (i966), Jordan (1978)

Weslager (1969)

Hard (1977)

Kniffen and Glassie (1966), Bunten and Walton (1980) 
SINGIE SADDLE NOTCH-DOWN

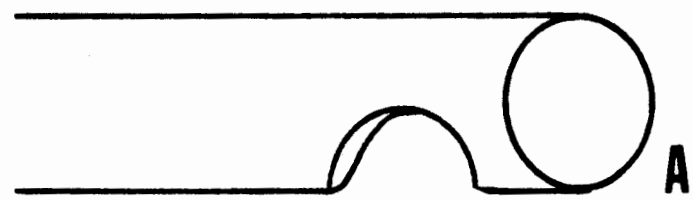

SINGLE SADDLE NOTCH-UP

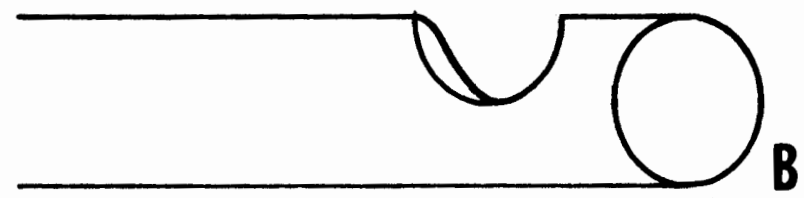

DOUBLE SADDLE NOTCH

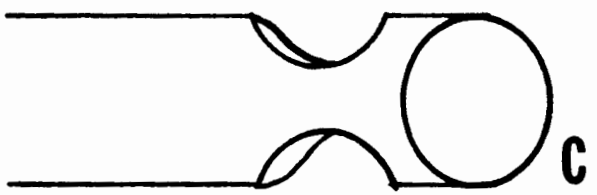

\section{SADDLE}

Figure 6. Saddle notches.

Other names assigned to these notches:

A. Saddle Notch

Round Notch

Single Saddle

Saddle Notch/Bottom

Round or Hog Pen Notch

Common Joint

\#4

Lock Joint

B. Saddle Notch/Top

Single Saddle

C. Double Notch

Double Saddle

Saddle Notch/Top and Bottom
Angier (1952), Bruyere and

Inwood (1975), Hard (1977)

Duncan (1978), Flaccus (1979),

Bealer and Ellis (1979)

Mason and Kock (1947), Beard

(1974), Mackie (1977), Ritchie

(1978)

Kniffen and Glassie (1966),

Jordan (1978), Bunten and

Walton (1980)

Weslager (1969)

Wiggington (1972)

Hunt (1939)

Popular Science (1952)

Brimmer (1929)

Weslager (1969)

Kniffen and Glassie ( 1966)

Jordan (1978), Bunten and

Walton (1980)

Brimmer (1929), Johnson (1970), Hard (1977)

Kniffen and Glassie (1966),

Jordan (1978), Bunten and

Walton (1980)

Weslager (1969) 

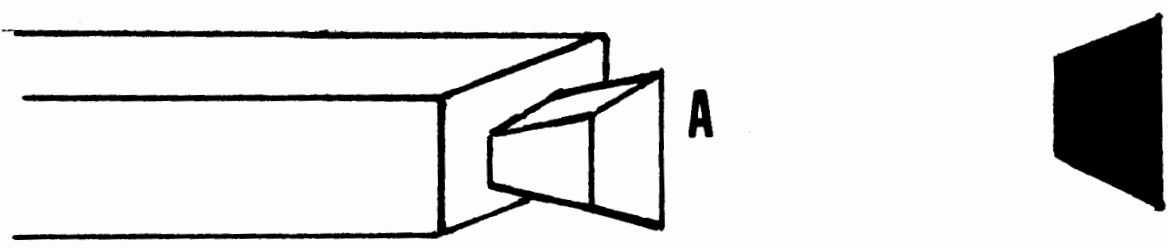

FULL DOVETAIL ON HEWN LOG
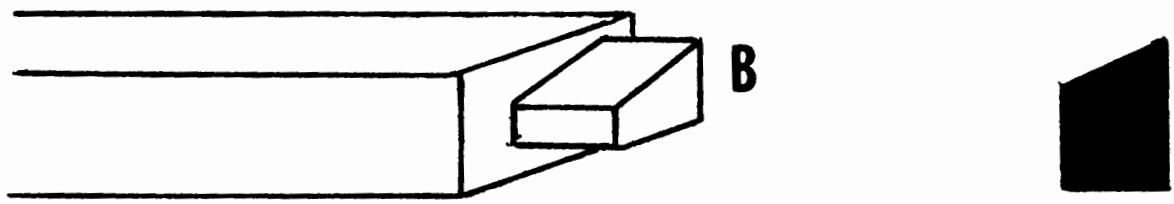

HALF DOVETAIL ON HEWN LOG

\section{DOVETAIL}

\section{Figure 7. Dovetail notches.}

Other names assigned to these notches:

A. Full Dovetail

Compound Dovetail Common Dovetail Dovetail

B. Half Dovetail

Dovetail

Double Dovetail

Compound Dovetail Mortised
Kniffen and Glassie (1966), Weslager (1969), Jordan (1978), Bunten and Wal ton (1980)

Mann and Skinulis (1979)

Hard (1977)

Angier (1952), Mackie (1977)

Kniffen and Glassie (1966) Weslager (1969), Mackie (1977), UicRaven (1978), Jordan (1978), Bealer and Ellis (1979), Bunten and Walton (1980)

Miggingtop (1972), Bealer (1974), Ritchie (1978)

Hard (1977)

Shurtleff (1939), Mason and Kock (1947) 


\section{a}

ROUNDED HALF NOTCH ON ROUND LOG

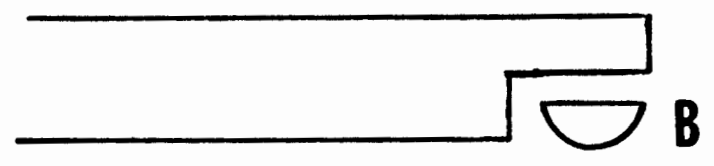

HALF NOTCH ON ROUND LOG

(False Corner Timbering)

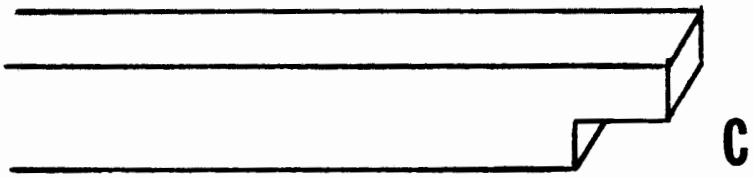

HALF NOTCH ON HEWN LOG

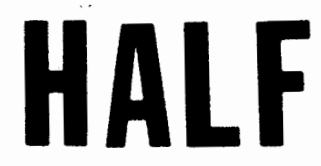

Flgure 8, Half notches.

Other names assigned to these notches:

A. Saddle-End

Rounded Halved \#8

B. Half Cut

General Putnam

Half Joint

Flat Notch

C. Half Notch

Half Notch and False

Corner

Lap or Rabbet joint

Flat or Square

Lap or Rebated Joint

(False Corner Timbering)

Halve-and-Lapped

Full Lapped Joint

Halved Corner/Hewn Log
Hard (1977), Duncan (1978)

Brimmer (1929)

Fopular Science (1952)

Hard (1977), Duncan (1978)

Beard (1974)

Brimmer (1929)

Bealer and Ellis (1979)

Weslager (1969)

Jordan (1978)

Hard (1977)

Bealer and Ellis (1979)

Kniffen and Glassie (1966)

Mason and Kock (1947)

Mackie (1977)

Shurtleff (1939) 


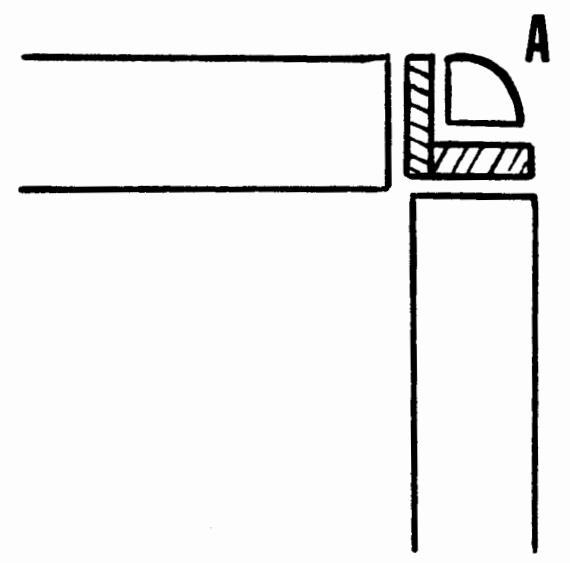

PLANK CORNER POST

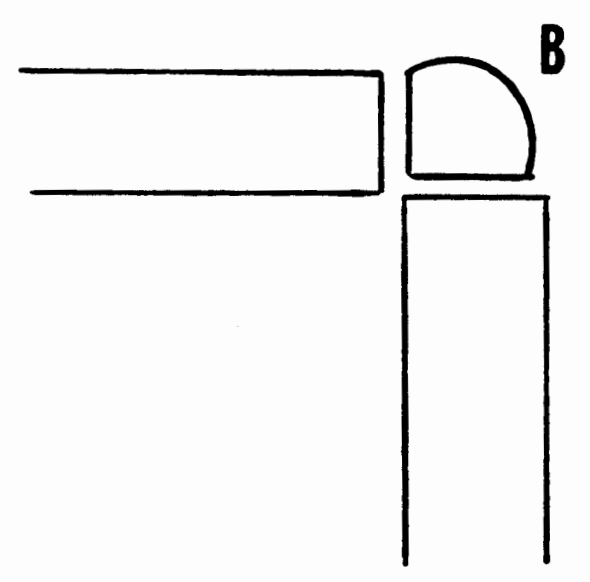

PLAIN CORNER POST

\section{CORNER POST}

\section{Eigure 9e Corner Posts. \\ Other names assigned to these notches:}

A. Plank Corner

Corner Post With Planks

Corner Post-Variant

Hog Trough

Trough Corner

$\# 1$

B. $\frac{1}{4}$ Post

Corner Post

$\frac{1}{4}$ Post Without Planks
Hunt (1939), Duncan (1978)

Angier (1952)

Hard (197?)

Kniffen and Glassie (1966)

Mason and Kock (1947)

Popular Science (1952)

Duncan (1978)

Hard (1977)

Angier (1952) 
full-dovetail has none. The only example of a dovetail notch on a round $\log$ in the study area was the half notch, so it is given as the third and final subdivision.

Corner posts are not a true notch so no articulation occurs between the logs. Logs are placed in a horizontal position above one another so the inner edges form a ninety-degree angle. They are then secured either to planks laid flush with the log ends, or with a post that has been cut in quarters (see Figure 9).

Other notch types may be observed and added within the appropriate categories. If this typological system is systematically used by those recording $\log$ structures much confusion and frustration will be eliminated. Some notch types have as many as eight different names so if only a verbal description is used uniformity is necessary.

4. Logs

A. Type (species). Unless bark remains on the logs, then identification of the species is difficult to determine in the field. A comparison of the local overstory with log types may show a correlation. Not only must logs be of a uniform size, but certain species are preferable for their workability, weight, and resistance to insects. In one instance (Glover 1981b:15) three different species were identified in the structure. Because the area has a mixed conifer vegetation community, a correlation between available and utilized species is possible.

In some cases the current local overstory species may not correlate to the species of logs used for the cabin. This would 
occur if recent reforestation altered the historic plant community. If there are any questions the responsible agency should be able to provide the reforestation history.

B. Finish. Jordan (1978:34) points out six methods of $\log$ preparation: unhewn, rough hewn, square hewn, planked, half log and hewn half log. As most log cabins within the study area are all round logs they should also be described as peeled or unpeeled. If deterioration is advanced the bark will have fallen of $f$. The best place to observe remaining bark is between the logs as logs naturally slough off the bark over time, though it tends to adhere longer between the logs.

C. Diameter. Logs naturally vary in size but most used for construction fall within a certain range. Most common is a diameter of $8-12$ inches or $18-38 \mathrm{~cm}$. Sill logs, which rest on the ground will be the largest, while the smaller logs are used near the gable. Observed during the collection of data was the tendency to use smaller logs (less than 6 inches diameter) for additions.

D. Chinking. To block wind and rain the space between logs is filled in. Historically, mining cabins were chinked with mud, bark, wood (the dimensions of lathing), or quarter-cut poles nailed to the logs. It is not uncommon to see a combination of two or more of these techniques. Other less common weatherization techniques include: tarpaper, newspaper, cardboard, boards, and metal. Where newspapers are used they may be helpful in determining the time span of occupation. 
E. Number. The number of logs used on a side varies with the side and condition of the structure. Because log cabins rot from the ground up, some structures may appear shorter than normal. Doorway and window height are good indicators of whether logs are missing through deterioration.

5. Doors: Doorways should be measured for width and height (if necessary). Many cabins are so deteriorated that height cannot be determined. If the door itself is present it should be described. When doors are missing the reasons for their disappearance are often unknown and speculation provides the only clues. Possible reasons include: vandalism, deterioration, or removal by the last occupant for use on another structure. Doors which have been observed usually are either planks or commercially made doors. The latter is not common, but has been noted on some occupied and altered cabins.

6. Windows: Like doors, windows are usually missing from the more decomposed cabins. If openings are discernible, they should be measured for dimensions and placement. Frames and castings when present should be described. Some structures have boards which are attached to the exterior of the window to winterize the building.

7. Roof covering: Most mining cabins have shake roofs though they are frequently reinforced with corrugated metal, tarpaper, and/or tin cans which have been split open and nailed to the roof. Because of the likelihood of harsher winds, rain, and lack of sunlight, these modifications are usually found on the north side. 
In one instance (Glover 1981b:13-18) a new roof of shakes was laid over the original roof. Of course, if there is severe deterioration there may not be a roof.

The best location to search for nails is on the roof shakes. In Eastern Oregon most settling and gold mining occurred after 1862. In nail typologies this would be after the introduction and general use of round machine-cut nails. In isolated areas nails may have also been reused. In other regions and states, however, nail typologies may be more useful.

Shelves and cupboards are sometimes located on the exterior of a structure and in more recent cabins, ice boxes are attached to an outer wall.

Interior. The interior of a cabin may have little recordable information due to deterioration, vandalism or lack of artifacts. Rats also like to nest inside abandoned cabins making visual inspection and breathing difficult. Deer have also been observed bedding down in cabins as have cattle.

8. Cellar: Most small log cabins do not have cellars. Only one cellar was recorded in the study area and that was under a "remodeled" cabin. Care of course should be taken when walking across wood floors as the board may have rotted over the cellar area.

9. Floor: Just as the exterior of a cabin rots from the ground up, so does the inside. The flooring, if made of wood, is the first thing to go. It is debatable whether most mining cabins had wood or dirt floors. Abandoned and deteriorated structures may show no 
evidence of wood floors while the occupied structures or recently occupied ones have either planks, boards, and sometimes linoleum flooring. If a plank or board floor cannot be verified, then "dirt" should be listed. Wood floors could also have been added either by the builder after living in the cabin for some time, or by a later occupant.

10. Interior Wall Finish: In small mining cabins where logs were left unpeeled and in the round, the interior wall and the exterior wall finishes are the same. Some builders did adze the interior walls or some logs on the inside. Why only a few selected logs or segments of logs were modified might be explained by the placement of lanterns, though this has not been confirmed. Again, newspapers, cloth, and bits of wood are sometimes stuffed between the logs to block cold air or rain.

11. Shelves/Cupboards/Hooks/Nails: There are few "built-ins" in log cabins, but a shelf or two is not uncommon. Some "cupboards" are described more accurately as simply packing cases made of wood which have been adapted for use as a cupboard. Hooks are sometimes found in walls and ceilings. Interior nails may be visible in rafters, walls and floors when present.

12. Windows: Windows are much the same when viewed from the insideas from the outside. Infrequently window coverings and hardware (nails and hooks) may be observed on the inside.

13. Heating/Cooking Area: Even when there are no stoves within the cabin the heating and cooking area can be essily determined by looking for the stovepipe hole in the wall or roof, or scorch marks 
on the walls which give undeniable evidence of the placement of the stove. Some cabins have two walls with burn marks. This occurrence indicates either that two stoves were used simultaneously or that the location of the stove was changed. Allen (1930:188) asserts that stoves were in use by 1853 , though Jordan (1978:103) states: "after the Civil War, and particularly after 1875, most log houses were built without chimneys. Kitchen ranges and wood-burning cast-iron stoves replaced the hearth and fireplace..." Because the time of settlement of the study area was during the war few fireplaces would be expected. In fact, there are no known fireplaces in any mining cabins in the area. One cabin built in the 1920's and used as a mining cabin today does have a fireplace, though it appears to have been added later because the chimney has the basic metal stovepipe (Glover 1981b:36). Bits and pieces of metal stoves sometimes can be found outside the structure though no typologies have been done which make them usable as time markers. In some instances mail-order catalogs such as Sears and Roebuck may provide a means of identification and dating. Some portions may have a patent date which would be the easiest method of getting an "earliest" date for the artifact.

14. Ceiling: Ceilings are usually unfinished and just reveal the underside of the roof so anything different should be described.

\section{Artifacts}

Qutside Structures. Tin cans, bottles, equipment and other debris should beinspected and recorded. If dating of the structure is possible these 
materials may provide useful information. Unfortunately, the popularity of bottle collecting has depleted much of the diagnostic material from log cabin sites, though bottle hunters often prefer unbroken bottles and rarely take cans. If fragments of purple or amethyst-colored glass are found they indicate a minimum manufacture of 1916. After that time other chemicals were used in glassmaking which did not react to sunlight, causing such discoloration. Tin can typologies are useful in providing gross time-spans. Inside Structure. As with exterior artifacts, any portable material should be recorded. The most frequently observed cultural debris includes: chairs, tables, boxes, beds, bedsprings and stoves, which may be a recent introduction to the structure.

\section{Eeatures}

Type. As utilized here, the term feature refers to any man-caused alteration in the physical environment. Features particular to mining activity include: prospect holes, adits, shafts and tunnels, tailings from both placer (hydraulic) mining and lode (hard rock) mining, and ditches. While these types of features are the reason for existence of mining cabins, a direct association between features and structures cannot always be established. Where intensive mining has occurred there may be a variety of features near the cabin site, not all of which may be associated with the structure. If a claim name or claimant's name is known, then mining claims records will establish if the claim was for placer or lode mining, thus helping to ascertain the association. Where the records are not clear, then the site sketch map should indicate the location and a verbal description of the features.

Prospect Holes: Usually shallow depressions made during the prospecting phase of mining. Generally they measure from two to six meters 
in diameter and reach a depth of two to four meters. Due to the nature of this feature, prospect holes may have been dug by anyone and are not necessarily associated with the structure being recorded. Noting the size, position, and number of holes should be sufficient information in the site description.

Adits, Shafts and Tunnels: These features are the most complex of mining features. Adits extend horizontally, or at a slight slope, into the hillside. Adits do not continue through the hill like tunnels but stop before the opposite slope is reached. Shafts are dug straight down into the ground either from the surface or off of an adit or tunnel. Despite the temptation these features arouse, they should not be entered by the investigator. Several hazards exist in underground workings which would risk the life of the archaeologist. Along with danger of cave-ins, there are frequently noxious gases and the possibility that an unseen shaft will be fallen into. The Federal Government's Health and Safety Code prohibits entrance to these features except by or with trained mining engineers. If such features are currently being worked, the current claimant will frequently have maps which describe the extent of the workings. Adits, shafts and tunnels may be located by spotting the tailings (waste rock from the excavation).

Tailings: Large piles of rock which result from both placer and hard rock mining. Placer tailings are washed clean of dirt, found adjacent to stream courses, and sometimes alter the stream channel. Hard rock tailings are near the mouth or collar of the adit, shaft, or tunnel. In all cases, the rocks are unstable and easily dislodged (personal experience) by foot travel. General position, size and extent of tailings should be noted in the report. Ditches: Linear features which follow topography (side hill), average a 
meter in width and depth, and may cross streams and run for considerable distances. The purpose of ditches was to supply additional water for hydraulic mining and ore processing. When ditches extend for miles they probably have been disturbed by road construction and natural deterioration. The Badger Ditch (H-645-0077) on the Long Creek Ranger District is eight miles long, taps over six creeks, and has been obliterated in many areas by road construction (Glover 1981d). Noting the average width and depth, including the feature on the site map, and a verbal description within the site report should provide sufficient information.

The purpose of recording this information is to help delineate the relationship between structures and features. Unless a mining engineer accompanies the investigator into the subterranean features, general above-ground observations should suffice for the report.

\section{Condition}

This portion of the site report is used to give a general description of the condition of the site, and may be used to discuss the site's integrity, a step necessary in the evaluation process.

Vandalism. With the increased popularity of bottle hunting as a hobby, many mining cabin sites have been disturbed. Evidence of "pothunting" are holes dug near the cabin (usually within a few meters of the door) which are used to locate the dump area. Such disruption of sites may in no way be termed positive, but discarded cans and bottles or fragments of bottles may be helpful in dating the site. Sites may also have suffered from the removal of portable cultural material which is not apparent to the investigator. The structure itself may have had boards removed by those attracted to the 
weathered material, who use it for picture frames or paneling.

Deterioration. Deterioration is a natural process directly attributable to weathering and animal disturbance. Included within this category are rotted timbers, collapsed structure(s) and deterioration caused by pests such as termites, rats, and animals' gnawing on the protruding ends of the structure. The deterioration of features may include collapsed walls, regrowth of vegetation, and gullying caused by the breaking of the ditch. Artifacts deteriorate in a manner particular to the composition of the object; tin cans rust, bottles change color and rubber will crack and crumble. Any pertinent deterioration should be discussed within the report.

Alterations, Alterations may be defined as those human-caused changes in the property occurring subsequent to the original construction. A variety of alterations may be observed: $\log$ and plank additions attached to the original cabin, new roofs overlain on the original roof, new aluminum case windows, etc. The more recent the alteration, the easier it is to identify as being subsequent to original construction. Some clues include differing materials, workmanship, style, and relative deterioration.

Summary. Observation of the site's condition plays a major part in the evaluation and management process. The evaluation of significance may be partially based on the site's integrity. A site which has been vandalized, altered, and is severely deteriorated would require exceptional attributes in other areas which would of fset the condition. Depending on the level of management suggested, this information may either help document the process of deterioration or vandalism or may be used to guide rehabilitation efforts. 


\section{CONCLUSION}

The checklist may be usable as it stands, but because each site varies, so will the information needed. If there have been extensive alterations, another section should be added to accommodate them. This list was developed to standardize cabin descriptions and to serve as a guide. Even the most precise format is no substitute for photographs. At least two photogrephs should be taken for each structure: one which depicts the condition of the cabin and one of the notching. Site maps save much verbiage in the site report. A window, for example, may be noted as being on the south side, and the dimensions may be given on the site map. Orientation is more effective if expressed on the map. The main purpose for the physical description of the cabin is to describe the condition, determine the possible construction date, and to relate the structure to the resource category. If these are accurately described, then the evaluation and management alternatives will be appropriate for the site. Measuring every log and noting every nail is neither necessary nor appropriate; it is time-consuming, and yields little information. Sites that are earmarked in the management process for scientific investigation and/or interpretation may then be rigorously recorded, but that is best decided on a case-by-case basis. Federal guidelines specify that testing stops when enough information is gathered for the evaluation. Recording physical attributes of a cabin is part of the testing process, just as much as digging test pits in Native American sites. It is not the purpose of this thesis to describe the methodology that should be used in such potential scientific investigations, but to develop a method of recording mining cabin sites for evaluation and management by 
government agencies. A great amount of usable information can be recorded if the proposed checklists are used, but they do not replace guided scientific studies, nor will they answer all possible questions that could be asked. 


\section{CHAPTER IX}

\section{CONCLUSION}

The cultural resource data base for millions of acres of federal land is under the direction of archaeologists who must provide well planned and executed site descriptions. Those site descriptions should describe the physical remains of the site, relate the site to its category, suggest possible scientific and historical studies, and justify the evaluation and management suggestions.

Site descriptions have a three-fold function in cultural resource studies. First, they must clearly describe the physical appearance of the site, relate the site to the category being discussed, and utilize a consistent vocabulary and format which will permit further studies. The majority of cultural resource sites will not be chosen for preservation so the only systematically collected record may be the archaeologist's report. This factor underlines the necessity for clear, concise and accurate site reports. Second, site descriptions must provide information pertinent for site evaluations. As called for in the criteria of significance for the National Register of Historic Places, sites must be assessed for their significance in history, prehistory, scientific value, etc. The investigation described here helps to establish the typical site patterning of mining structures by utilizing census records and log notch preferences in the Old and New Worlds. This information provides a necessary and substantial basis for evaluating mining sites. And finally, management alternatives will be judged and selected 
through the information contained within the site report. The archaeologist must make a conscious effort to provide the reader with information necessary to weigh the alternatives presented.

With the massive cultural resource program being undertaken by the federal government, cultural resource site reports will be judged for the completeness of the physical description, and usefulness as evaluation and management tools. To be credible, cultural resource reports must meet both the demands of the scientific community and the governing agency. 


\section{LIST OF REFERENCES}

Allen, Edith Louise

1930 American Housing as Affected by Social and Economic Conditions. Peoria, IL: Manual Arts Press.

Angier, Bradford

1952 How to Build Your Home in the Woods. New York: Hart Publishing Co.

1980 Looking for Gold: The Modern Prospector's Handbook. Harrisburg, PA: Stackpole Books.

Barlow, Jeffrey and Christine Richardson

1979 China Doctor of John Day. Portland, OR: Binford and Mort.

Barnes, Mark Alton, K. Briggs and Jerry J. Neilson

1980 A Response to Raab and Klinger on Archaeological Site

Significance. American Antiquity 45[3]:551-553.

Barry, Frances

1973 Chinese in the Mining Camps. Unpublished Paper. John Day, OR: Grant County Library.

Bealer, Alex W. and John O. Ellis

1979 The Log Cabin, Home of the North American Wilderness. Barre MA: Barre Publishing.

Beard, D.C.

1974 Shelters, Shacks and Shanties. New York: Charles Scribners Sons. Originally printed in 1914.

Beckham, Stephen Dow

1978 Identifying and Assessing Historical Cultural Resources in the

Pacific Northwest. Studies in Cultural Resource Management No. 2,

Region 6, U.S.F.S.

Blower, James

1971 Gold Rush. New York: American Heritage Press.

Bright, Verne

1961 Blue Mountain Eldorados: Auburn 1861. Oregon Historical

Quarterly, Volume LXII No. 3.

Brimmer, F.E.

1929 Camps, Log Cabins, Lodges and Club Houses. New York: D. Appleton and Co. 
Bruyere, Christian and Robert Inwood

1975 In Harmony with Nature, Creative Country Construction. New York: Drake Publishers.

Clark, Thomas D.

1959 Frontier America, Westward Movement. New York: Scribner.

Clemson, Donovan

1974 Living with Logs, British Columbia's Log Buildings and Rail Fences. Saanichtion, BC, Canada: Hancock House Publishers.

Constance, Clif ford L.

1960 Chronology of Oregon Schools, 1834-1958. Eugene, OR: University of Oregon Books.

Conway, Alan

1961 The Welsh in America, Letters from Immigrants. St. Paul North

Central Publishing Company.

Davidson, Marshall $B$.

1971 The American Heritage History of Notable American Houses. New

York: American Heritage Publishing Company.

Davis, Jean

1966 Shallow Diggin's Tales from Montana Ghost Towns. Caldwell, ID: Caxton Printers.

Dicken, Samuel N. and Emily F. Dicken

1979 Two Centuries of Oregon Geography: The Making of Oregon, A

Study in Historical Geography. Portland, OR: Oregon Historical

Society.

Duncan, S. Blackwell

1978 How to Build Your Own Home and Cabin from Scratch. Blue Ridge Summit, PA: Tab Books.

Fay, Albert $\mathrm{H}$.

1920 A Glossary of the Mining and Mineral Industry. Department of Interior Bulletin 95, W ashington D.C.: Government Printing Office.

Ferrell, Mallory Hope

1967 Rails, Sagebrush and Pine. San Marina, CA: Golden West Books.

Fisher, Vardis, and Opal Laurel Holmes

1968 Gold Rushes and Mining Camps of the Early American West. Caldwell, ID: Caxton Printers.

Flaccus, Edward

1979 North Country Cabin. Missoula, MT: Mountain Press Publishing. 
Gaston, Joseph

1912 The Centennial History of Oregon, 1811-1912, Volume I. Chicago,

IL: S.J. Clarke Publishing Co.

Gilluly, James, J.C. R eed and C.F. Parks, Jr.

1933 Some Mining Districts of Eqstern Oregon. Geological Survey, Bulletin 846 A.

Glessow, Michael A.

1977 Issues in Evaluating Significance of Archaeological Resources.

American Antiquity 42[3]:413-420.

Gudde, Erwin G.

1975 California Gold Camps, A Geographical and Historical Dictionary of Camps, Towns and Localities Where Gold $W$ as Found and Mined; Wayside Stations and Trading Centers. Los Angeles, CA: University of California Press.

Hard, Roger

1977 Build Your Own Low-Cost Log Home. Charlotte, VT: Gardenway Publishing.

Harris, Cyril M. (Editor)

1977 Historic Architecture Source Book. New York: McGraw-Hill.

Hines, Rev. H.K.

1893 An Illustrative History of the State of Oregon. Chicago, IL: Lewis Publishing Company.

How to Build Cabins and Ranch Houses. Prepared by the Editorial Staff. 1952 New York: Popular Science Publishing Company.

Hunt, W. Ben

1939 How to Build and Furnish a Log Cabin, The Easy-Natural Way

Using Only Hand Tools and the Woods Around You. New York: Macmillan Publishing Co.

Hutslar, Donald A.

1974 Log Cabin Restoration: Guidelines for the Historical Society. Technical Leaflet \#74, Nashville, TN: American Association of State and Local History.

Hyatt, David E.

1973 The Environmental Impact Statement: A New Requirement in

Planning the Mining Operation. Mineral Industries Bulletin, Volume 16, No. 3, May.

An Illustrated History of Baker, Grant, Malheur and Harney Counties. 1902 Western Historical Publishing Company.

Jackson, Donald Dale

1980 Gold Dust. New York: Alfred A. Knopf. 
Johnson, Edward L.

1970 The Wilderness Cabin. Copyright held by Edward L. Johnson, U.S.A.

Jordan, Terry G.

1978 Texas Log Buildings, A Folk Architecture. Austin, TX: University of Texas Press.

Klinger, Timothy C. and Mark Raab

1980 Archaeological Significance and the National Register: A Response to Barnes, Briggs and Neilson. American Antiquity 45[3]:554-557.

Kniffen, Fred and Henry Glassie

1966 Building in Wood in the Eastern United States, A Time-Place Perspective. Geographical Review.

Lew is, Marvin

1967 The Mining Frontier, Contemporary Accounts from the American West in the Nineteenth Century. Norman, OK: University of Oklahoma Press.

Lyman, Horace $\mathrm{S}$.

1903 History of Oregon, The Growth of an American State. New York: The North Pacific Publishing Society.

MeArthur, Lewis A.

1974 Oregon Geographical Names, 4th Edition, Portland, OR: Oregon Historical Society.

McRaven, Charles

1978 Building the Hewn Log House. New York: Thomas Y. Crowell Publishers.

Mackie, B. Allan

1977 Notches of All Kinds, A Book of Timber Joinery. The Canadian Log House, British Columbia.

Mann, Dale and Richard Skinulis

1979 The Complete Log House Book, A Canadian Guide to Building with Logs. San Francisco, CA: McGraw-Hill Ryerson Ltd.

Mason, Bernard S. and Frederic H. Kock

1947 Cabins, Cottages and Summer Homes. New York: A.S. Barnes and Co.

Merrill, William

1974 Wood Deterioration: Causes, Detection and Prevention. Technical Leaflet \#77, Nashville, TN: American Association of State and Local History.

Morgan, Murray

1967 One Man's Gold Rush, A Klondike Album. Seattle, WA: University of Washington Press. 
Morris, Richard B. (Editor)

1965 Encyclopedia of American History. New York: Harper and Rowe.

Morrison, Hugh

1952 Early American Architecture from the First Colonial Settlements to the National Period. New York: Oxford University Press.

Mumford, Lewis

1955 Sticks and Stones, Study of American Architecture and Civilization. New York: Dover Publishers. Copyright 1924.

Nedry, H.S.

1952 Notes on the Early History of Grant County: Oregon Historical Quarterly. Vol. 53, No. 4, pp 235-254, December.

Oliver, Herman

1961 Gold and Cattle Country. Portland, OR: Binford and Mort.

Oregon's Gold Placers

1957 Miscellaneous Paper No. 5 (Second Printing). State of Oregon, Department of Geology and Mineral Industries, Portland, OR.

Potter, Miles F.

1976 Oregon's Golden Years. Caldwell: ID, Caxton Printers.

Preston, Ralph N.

1972 Early Oregon Atlas. Portland, OR: Binford and Mort.

Raab, Mark L. and Timothy Klinger

1977 A Critical Appraisal of "Significance" in Contract Archaeology. American Antiquity. 42[4]:629-634.

1979 A Reply to Sharrock and Grayson on Archaeological Significance. American Antiquity. 44[2]:328-329.

Rand, Helen B.

1959 Gold and Oregon's Settlement. The ORE-BIN, Vol. 21, No. 5, May.

Rapoport, Amos

1969 House Form and Culture. Englewood Cliffs, NJ: Prentice-Hall.

Rickard, T.A.

1966 A History of American Mining. New York: McGraw-Hill Book Co. Johnson Reprint Corporation. Originally printed in 1932.

Ritchie, James $D$.

1978 Successful Log Homes. Farmington, MI: Structures Publishing Co.

Rutistrum, Calvin

1975 The Wilderness Cabin. How to Build Your Own Log, Frame, or Adobe Cabin and Where to Build It. New York: MacMillan. 
Scott, Harvey $w$.

1924 The History of the Oregon Country, Volume III, by Harvey W. Scott, Forty Years Editor of the Morning Oregonian. Compiled by Leslie M. Scott. Cambridge, MA: Riverside Press.

Sharrock, Floyd W. and Donald K. Grayson

1979 Significance in Contract Archaeology. American Antiquity $44[2]: 327-328$.

Shurtleff, Harold Robert

1939 The Log Cabin Myth: A Study of the Early Dwellings of the English Colonists in North America. Cambridge, MA: Harvard University Press.

Sloane, Howard N. and Lucille Sloane

1970 A Pictorial History of American Mining. New York: Crown Publishers.

Steward, Elinor Pruitt

1914 Letters of a Woman Homesteader. Cambridge, New York and Boston: Houghton Mifflin Co. The Riverside Press.

Trimble, William J.

1914 The Mining Advance into the Inland Empire. PhD. Dissertation,

Madison WI: Bulletin of the University of Wisconsin \#638. History

Series, Volume 3, No. 2, pp 137-392.

Wagner, N. S.

1967 Mineral Resources - Grant County, Oregon. A Review Prepared at the Request of the Grant County Planning Commission by the Department of Geology and Mineral Industries, State of Oregon.

Wallace, Robert

1976 The Miners, the Old West. Alexandria, VT: Time-Life Books.

Watkins, T. H.

1971 Gold and Silver in the West, The Illustrated History of A Dream.

Palo Alto, CA: American West Publishing Co.

Weslager, Clinton Alfred

1969 The Log Cabin in America; From Pioneer Days to Present. New Brunswick, NJ: Rutgers University Press.

Wiggington, Eliot (Editor)

1972 The Foxfire Book. Garden City, NY: Anchor Books. 
FEDERAL, STATE, AND LOCAL GOVERNMENT DOCUMENTS

Ayers, Gary G., Hudson Lorka, and George F. Gauzza

1978 Cultural Resource Overview of the Malheur National Forest, Long Creek Ranger District Section, Volumes I and II.

Brown, C. Ervin and T. P. Thayer

1966 Geologic Map of the Canyon City Quadrangle, Northeastern Oregon.

Bunten, Hugh and Patrick Walton

1980 Archaeological and Historical Data Recording Guide, Fremont

National Forest. Pacific Northwest Region.

Carlson, Garwin

1974 Soil Resource Inventory, Malheur National Forest, Basic Soil Information and Interpretive Tables. August.

Dierking, Roger F.

1980 Mining Claim Records. Letter from the U.S.D.A., Bureau of Land Management, Branch of Records and Management, July.

Federal Census for 1870

Baker, Grant, Umatilla and Union Counties, Eastern Oregon. Typed from Microfilm and Indexed by Mrs. Harry I. Hiday. Duplicated by Offset at The Ink Spot, Salem, Oregon.

Federal Census for 1880

Grant County, Eastern Oregon. Copied from Microfilm by Jeanne M. Duncan Secord, Dorian Chapter D.A.R. Printed in John Day, Oregon, August 1971.

Final Environmental Statement

USDA-FS-FES-(Adm)-76-3, John Day Planning Unit, Malheur National Forest, Forest Service, U.S.D.A., 1978.

The Geologic Setting of John Day Country,

Grant County, Oregon. U.S. Department of Interior/Geologic Survey, USGS: INF-69-10.

Glover, Margaret, Lois Stanford and Jody Turner

1979 a Granite Boulder Timber Sale Report, 645-79-001. Malheur National Forest, John Day, Oregon. 
1979b Lost Meadows Timber Sale Report, 645-79-005. Malheur National Forest, John Day, Oregon.

Glover, Margaret

1980 a Cultural Resource Survey Report for Cogo Timber Sale. Vol. I, 645-80-007. Malheur National Forest, John Day, Oregon.

1980b Cultural Resource Survey Report for Cogo Timber Sale. Vol. II, 645-80-007. Malheur National Forest, John Day, Oregon.

1981a Cultural Resource Survey for Mining Cabins. Vol. I, 645-81-015. Malheur National Forest, John Day, Oregon.

1981b Cultural Resource Survey for Mining Cabins. Vol. II, 645-81-015. Malheur National Forest, John Day, Oregon.

1981c Cultural Resource Survey for Crockett Knob Timber Sale. Vol. I, 645-81-017. Malheur National Forest, John Day, Oregon.

1981d Cultural Resource Survey for Crockett Knob Timber Sale. Volume II, 645-81-017. Malheur National Forest, John Day, Oregon.

Land Status Atlas, Title and Encumbrance Records

1970 Long Creek Ranger District, Malheur National Forest, John Day, Oregon.

Record of Mining Claims for Grant County,

Grant County Courthouse, Canyon City, Oregon, 1862-present.

The Secretary of Interior's Standards for Rehabilitation

and Guidelines for Rehabilitation of Historic Buildings. Office of

Archaeology and Historic Preservation, Heritage Conservation and Recreation Service.

Steggell, Norman

1980 Letter to Recreation Staff Officer, Subject: Long Creek District Cultural Resource Reports. October 30, 1980. Malheur National Forest, John Day, Oregon.

Wildesen, Leslie

1977 Cultural Resource Management: A Guide Book of Procedures and Techniques for Managing Historical and Archaeological Resources. Forest Service - U.S.D.A., Pacific Northwest Region. 


\section{LAWS AND FEDERAL REGULATIONS}

Executive Order 11593,

Protection and Enhancement of the Cultural Environment: 36 F.R. 8921, May 13, 1971.

National Environmental Policy Act:

P.L. 91-190; 83 Stat. 852; 42 U.S.C. 4321.

36 CFR 60.6 National Register Criteria for Evaluation

36 CFR 252 National Forest Mineral Resources - U.S.D.A. Rules on Prospecting, Exploration and Mining Procedures; Effective 9-1-74.

36 CFR 800 Procedures for the Protection of Historic and Cultural Properties, Guideline.

Public Law 91-631, Mining and Mineral Policy Act of 1970.

Proposed Forest Service Manual 2361. U.S.D.A. Forest Service. 